\title{
The Neolithic variscite mines of Gavà, Catalonia: criteria for mineral exploration and exploitation in the Prehistory
}

Yael Díaz-Acha, Joan Carles Melgarejo, Josep Bosch, Aleu Andreazini, Míriam Pastor, Núria Pujol-Solà, Marc Campeny, Lisard Torró, Cristina Villanova-de-Benavent, Montgarri Castillo-Oliver, Saleh Lehbib, Antoni Camprubí, Joaquín A. Proenza

Yael Díaz-Acha

Marc Campeny

Museu de Ciències Naturals de Barcelona. Parc de la Ciuta-

della s/n, 08003 Barcelona, Spain.

\section{Joan Carles Melgarejo}

Aleu Andreazini

Míriam Pastor

Núria Pujol-Solà

Joaquín A. Proenz

Departament de Mineralogia, Petrologia i Geologia Aplicada,

Facultat de Ciències de la Terra, Universitat de Barcelona.

Martí i Franquès s/n, 08028 Barcelona, Spain.

Josep Bosch

Museu de Gavà. Plaça de Dolors Clua, 13, 08850 Gavà,

Barcelona, Spain.

\section{Lisard Torró}

Departament de Mineralogia, Petrologia i Geologia Aplicada, Facultat de Ciències de la Terra, Universitat de Barcelona.

Martí i Franquès s/n, 08028 Barcelona, Spain.

Departament de Geologia, Facultat de Ciències, Universitat Autònoma de Barcelona. Edifici Cs, 08193 Bellaterra (Cerdanyola del Vallès), Spain.

Departamento de Ingeniería de Minas, Pontificia Universidad Católica de Perú. Avenida Universitaria 1801, San Miguel, Lima 32, Peru.

Cristina Villanova-de-Benavent

School of Environment and Technology, University of Brighton. Mithras House, Lewes Rd., Brighton BN2 4AT, United Kingdom.

\section{Montgarri Castillo-Oliver}

Departament de Mineralogia, Petrologia i Geologia Aplicada, Facultat de Ciències de la Terra, Universitat de Barcelona. Martí i Franquès s/n, 08028 Barcelona, Spain.

ARC Centre of Excellence for Core to Crust Fluid Systems and GEMOC, Department of Earth and Planetary Sciences, Macquarie University.NSW 2019, Australia.

\section{Saleh Lehbib}

Departament de Mineralogia, Petrologia i Geologia Aplicada, Facultat de Ciències de la Terra, Universitat de Barcelona. Martí i Franquès s/n, 08028 Barcelona, Spain.

Ministery of Water and the Environment, Sahrawi Arab Democratic Republic.

\section{Antoni Camprubí}

Instituto de Geología, Universidad Nacional Autónoma de México. Ciudad Universitaria, 04510 Coyoacán, CDMX, Mexico.

BOL. SOC. GEOL. MEX. 2019

VOL. 71 NO. 2

P. $295-319$

http://dx.doi.org/10.18268/BSGM2019v7 1n2a5

Manuscript received: January 15, 2018.

Manuscript accepted: May 8, 2018.

\section{ABSTRACT}

The Gavà Neolithic Mining Complex (GNMC) located in Catalonia was devoted to the exploitation of green variscite used in the crafting of ornaments. Archaeological works in more than 100 mines indicated that this mining activity was carried out $\sim 5800$ years before present. GNMC constitutes (1) one of the earliest known examples of underground mining in Europe, (2) the earliest example of large-scale mining for ornamental use, and $(\mathrm{C})$ the earliest of the application of complex geological and mining concepts. In the GNMC variscite is found as two distinct styles: (1) replacement of thin fluorapatite beds, which are interbedded with pyritic organic-rich black shales of Silurian age; and (2) veinlets crosscutting these materials. This set of geological materials is unconformably covered locally by Quaternary calcretes. Variscite formed as a result of Ouaternary supergene processes, which oxidized the pyrite and produced acidic, oxidized solutions. The resulting fluids mobilized phosphate from apatite and leached $\mathrm{Al}$ and organic matter out of Silurian shales, thus leading to the precipitation of the Al-rich phosphates as vein infilling and strata-bound replacements after apatite. The formation of variscite is restricted to the extent of the oxidizing front, and variscite of both mineralization style changes in color from yellowish green near the surface to deep green in depth. The study area contains two mining fields: Can Tintorer and Can Badosa-Les Ferreres range. The presence of abundant subvertical variscite veins in Can Tintorer allowed a complex development of galleries at different exploitation levels communicated by shafts and ramps, achieving 15 meters depth. The exploitation by Neolithic miners was by overhand and underhand stoping; they also used pillars and refilling of older exploitations to avoid the mine collapsing. These mines were opened in many cases by shafts that were dug directly through hard Quaternary calcretes, favoring the galleries' stability and revealing that miners understood that mineralization continues underneath th calcrete cover. Geological mapping reveals that exploitations in the Can Badosa-Les Ferreres area are simple, showing a single entrance to simple galleries or ramps attaining less than $5 \mathrm{~m}$ in depth and directly excavated on phosphate outcrops. Contrastingly, the mines in the Can Tintorer area have several entrances that consist of vertical shafts through a Quaternary cover, presenting an intricate geometry with many large and communicated galleries at different depths with a system of cameras and pillars. Although the development of both mining areas was essentially contemporaneous, the Can Badosa-Les Ferreres area can only be considered an exploration area. In addition, mining was carried out on minerals adjacent to variscite, not directly on variscite veins themselves, thus indicating that the miners were effectively using a wealth of geological knowledge that was previously acquired in the complex operations in the Can Tintorer mines.

Keywords: variscite, veinlets, replacement, supergene, Quaternary, stoping, Neolithic, mine protohistoric mining.

\section{RESUMEN}

El Complejo Minero Neolítico de Gavà (CMNG) ubicado en Cataluña tuvo como objeto la explotación de la variscita verde utilizada para la elaboración de adornos y joyería. Los trabajos arqueológicos en más de 100 minas indican que la minera en este complejo se llevó a cabo $\sim 5800$ años antes del presente. CMNG constituye (A) uno de los primeros ejemplos conocidos de minería subterránea en Europa, (B) posiblemente el ejemplo más antiguo de minería a gran escala para uso ornamental y $(C)$ el ejemplo más antiguo de aplicación de conceptos geológicos y mineros complejos. En el CMNG, la variscita se encuentra en dos estilos distintos: (1) reemplazamientos de láminas delgadas de fluorapatito intercaladas con pizarras negras ricas en minerales orgánicos de edad silúrica y (2) vetillas que cortan transversalmente estos materiales. El conjunto está cubierto discordantemente y localmente por caliches del Cuaternario. La variscita se formó como resultado de procesos supergénicos cuaternarios que oxidaron la pirita produciendo soluciones ácidas y oxidadas. Los fluidos resultantes movilizaron fosfato de apatito y lixiviaron Al y materia orgánica de las pizarras, lo cual condujo a la precipitación de los fosfatos ricos en Al como rellenos de venas y de reemplazamientos estratoligados de apatito. La formación de variscita se restringió a la extensión del frente de oxidación, y la variscita de ambos estilos de mineralización varia de color verde amarillento, en superficie, hasta verde profundo, en profundidad. El área de estudio contiene dos campos mineros: Can Tintorer y Can Badosa-Les Ferreres. La presencia de abundantes vetas subverticales de variscita en Can Tintorer permitió un complejo desarrollo de galerías en diferentes niveles de explotación comunicadas por pozos y rampas, logrando 15 metros de profundidad. La explotación empleada por los mineros neolíticos fue mediante realce ascendente y descendente; también usaron pilares y rellenos de explotaciones más antiguas para evitar el colapso de la mina. Estas minas fueron abiertas en muchos casos por pozos que fueron cavados directamente en duros caliches cuaternarios, favoreciendo la estabilidad de las galerías y revelando que los mineros comprendían la continuidad de la mineralización por debajo de la cubierta de caliches. El mapeo geológico revela que las explotaciones en el área de Can Badosa-Les Ferreres son simples, mostrando una entrada única a galerías simples o rampas que alcanzan menos de $5 \mathrm{~m}$ de profundidad y excavadas directamente en afloramientos de fosfatos. En contraste, las minas en el área de Can Tintorer tienen varias entradas y consisten en pozos verticales a través de una cubierta cuaternaria, presentando una intrincada geometría con muchas galerías grandes y comunicadas a diferentes profundidades con un sistema de cámaras y pilares. Aunque el desarrollo de ambas áreas mineras fue esencialmente contemporáneo, Can Badosa-Les Ferreres puede considerarse como un área de exploración. Además, la minería se llevó a cabo en minerales adyacentes a la variscita, no directamente en las venas de variscita, lo cual indica que los mineros usaron de forma efectiva un caudal de conocimiento geológico que se adquirió previamente a las complejas operaciones en las minas de Can Tintorer.

Palabras clave: variscita, vetillas, reemplazamiento, supergénico, Cuaternario, explotación por realce, Neolítico, mina, minería protohistórica. 


\section{Introduction}

Variscite is a hydrated aluminum phosphate $\left(\mathrm{AlPO}_{4} \cdot 2 \mathrm{H}_{2} \mathrm{O}\right)$ normally formed by supergene processes on phosphate-rich aluminous rocks. This mineral can be generated in soils and caves, as well as in lateritic surfaces or as a weathering product of sedimentary phosphates (Melgarejo et al., 1997). Variscite develops colorless, reddish or apple-green, small orthorhombic crystals. However, the most famous variscite varieties (also known as callaite or utahlite, among other names; Manutchehr-Danai, 2000), used for thousands of years to produce ornaments, are cryptocrystalline, with a typical pale bluish-green to yellowish-green hue.

The use of variscite for ornament crafting has been historically recorded since Neolithic times in many Western European countries, where the corresponding mining sites have been found. Significant examples have been reported in northern Portugal (Meireles et al., 1987), France (Herbaut and Querré, 2004), and in southwestern (Odriozola et al., 2010, 2013) or western Spain (Fernández-Turiel et al., 1995; Villalobos and Odriozola, 2016). Also, variscite has had an ornamental use by the indigenous populations of North America (e.g, Pueblo Bonito in New Mexico; Ball, 1941), and South America (e.g, Taironas in Colombia; Acevedo et al., 2016).

Variscite ornaments were relevant subjects for trade in prehistoric societies. Consequently, most archaeological studies have been focused on constraining the sources for variscite in order to establish the extension of the trade networks (i.e., Edo et al., 1990; Fernández-Turiel et al., 1990; Domínguez-Bella, 2004; Borrell and Bosch, 2012). Variscite exploitations may additionally provide valuable information on mining procedure and geological knowledge during Neolithic times (Costa et al., 1994; Camprubí et al., 2003).

Variscite outcrops are common in the Catalan Coastal Ranges. Nevertheless, only the Gavà mines are recognized as a source of material during the Neolithic. The extensive mining devel- oped in the Gavà area accounts for over 100 mining operations so far discovered by archaeological endeavors, including galleries, shafts, and trenches as old as 5800-5700 BP (or 3800-3700 BC; Alonso et al., 1978; Villalba et al., 1986, 1989, 1990; Blasco et al., 1991, 1992; Bosch et al., 1987, 1996; Villalba, 2002; Borrell et al., 2009, 2015; Borrell and Bosch, 2012). Therefore, the Gavà mines are a valuable source of information and are counted amongst the oldest known underground mines in the world (Camprubí et al., 2003). In fact, these are the oldest known underground mines in Europe that used galleries at different levels of exploitation (Blasco et al., 2000). Many of these mines were also used as graves during the Neolithic (Borrell et al., 2005), and many artifacts were found in them. Among these are a fertility goddess figure (the Gavà Venus; Bosch and Estrada, 1994), silex tools (Borrell, 2009), complete variscite beads (Figure 1; Borrell and Estrada, 2009), obsidian tools (Bosch et al., 2009), and pottery (Borrell and Orri, 2009; Bosch and Gómez, 2009). After their archaeological excavation, some of these mines have been

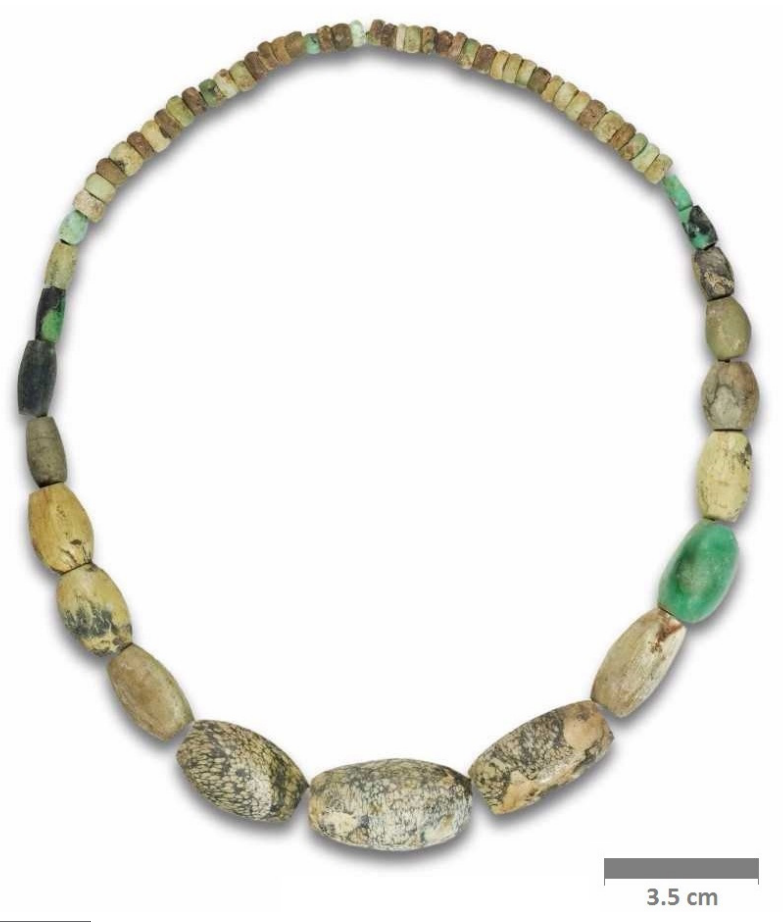

Figure 1 Necklace made from variscite beads of different colors from the grave goods of the burial at the Neolithic 83 mine, Gavà. 


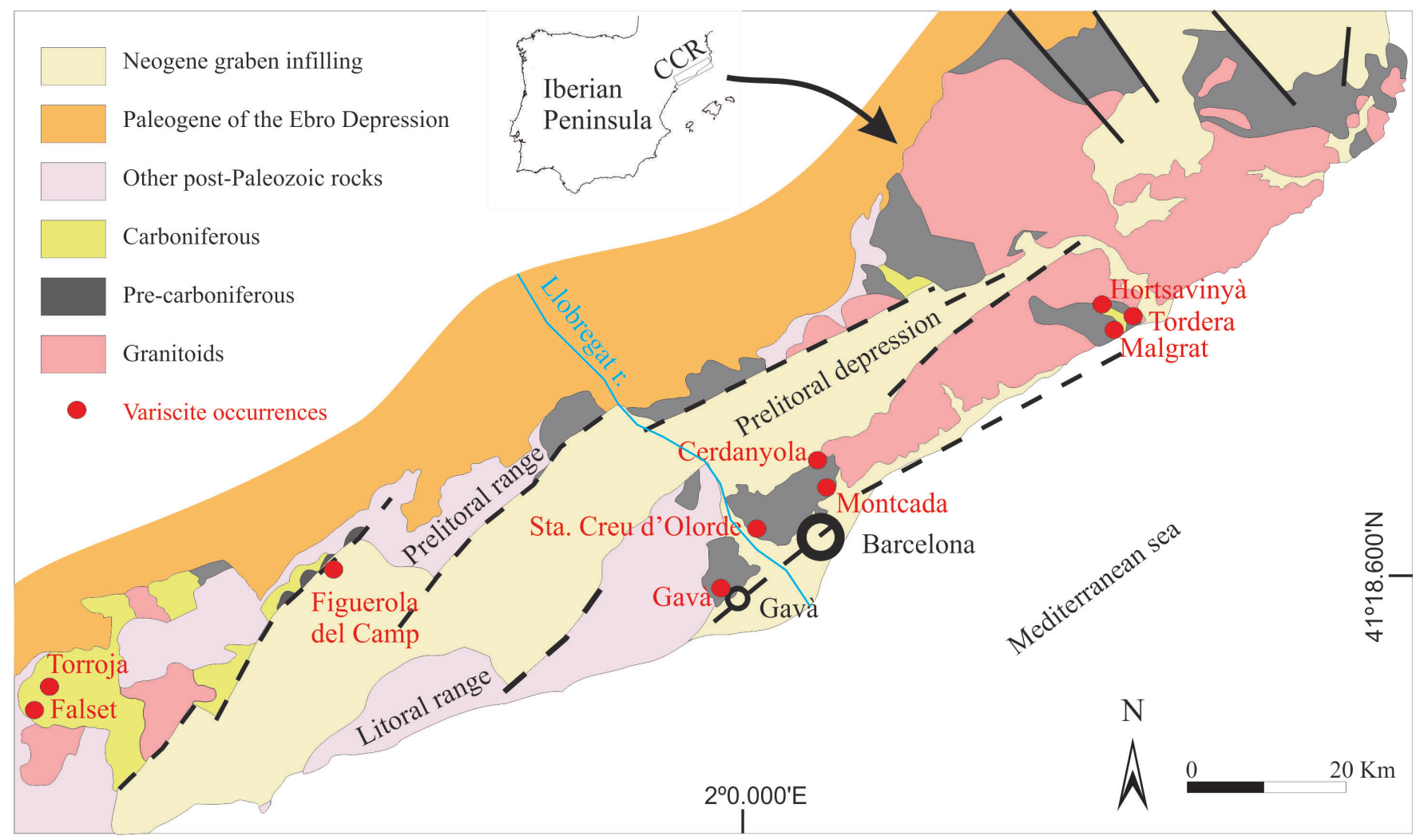

Simplified geological map of the Catalan Coastal Ranges (CCR) and location of variscite occurrences.

adapted and opened to the public as the on-site Archaeological Museum of the Gavà Mines (Blasco et al., 2000).

Geological mapping of the Gavà Neolithic mines (Costa et al., 1994; Camprubí et al., 2003) demonstrated that miners learned about the tridimensional arrangement of the variscite mineralizations, provided they organized the galleries accordingly. Ongoing archeological excavations during the last 15 years have uncovered hundreds of meters of galleries and shafts. During that time, complex systems of galleries up to $15 \mathrm{~m}$ deep have been mapped and characterized. Accordingly, the aim of this study is to provide new information on the geology of the Gavà Neolithic Mining Complex, in order to deduce the criteria used by the ancient miners to explore and exploit variscite resources, and also their wealth of knowledge of the regional geology.

\section{Geological background}

The Gavà Neolithic Mining Complex (GNMC) consists of many underground mines that are clustered in the town and vicinities of Gavà, $20 \mathrm{~km}$ southwest of Barcelona (Catalonia). During the 1960s, urban growth covered many of the mining areas, but, fortunately, the Municipality of Gavà and the Catalan Government have made efforts to protect these archaeological sites, and many mines have been preserved for research.

The Gavà area is located in the Littoral Range (Figure 2), one of the tectonic and morphological units that constitute the Catalan Coastal Ranges (CGR). The GCR roughly consist of two ranges (Prelittoral and Littoral) that strike NE-SW, are approximately parallel to the coastline, and are separated by the Prelittoral Depression (Anadón et al., 1979). The main geological units in these 
ranges are (1) a Paleozoic basement, deformed and metamorphosed during the Hercynian orogeny; and (2) Mesozoic sedimentary rocks, which unconformably cover the Paleozoic basement. The GCR generally shows regional and contact metamorphism associated with the intrusion of calc-alkaline plutons (Enrique, 1990), both metamorphisms are related with the Hercynian orogeny. The later Alpine orogeny is responsible for the reactivation of the ranges. An early compressive stage during the Paleogene produced NE-SWand NNW-SSE-trending strike-slip faults. The later reactivation of these fractures as normal faults during the Neogene shaped the current system of horsts and grabens (Anadón et al., 1985). One of the grabens is the Prelittoral Depression and it was subsequently filled by Neogene detrital series. The variscite deposits are found in the
Paleozoic basement in several localities along the CGR (e.g., Gavà, Montcada i Reixac, Santa Creu d'Olorda, Malgrat de Mar; see Figure 2), although consistent evidence for ancient variscite mining has been found only in Gavà.

The characteristic geological units that constitute the GCR are found in the Gavà area (Figure 3): a Paleozoic metamorphic basement; an unconformable cover of Mesozoic sedimentary rocks; and a regional extensional fault, which occurs at the SE limit of the basement, partly covered by Quaternary sediments and calcrete (Costa et al., 1994). The Paleozoic series is poorly defined in the mining area due to strong faulting and thrusting. However, it can be reconstructed by correlation with the well-established series in the neighboring Collserola range (Julivert and Duran, 1990; GarcíaLópez et al., 1990, 1996). It consists of sulfide-rich

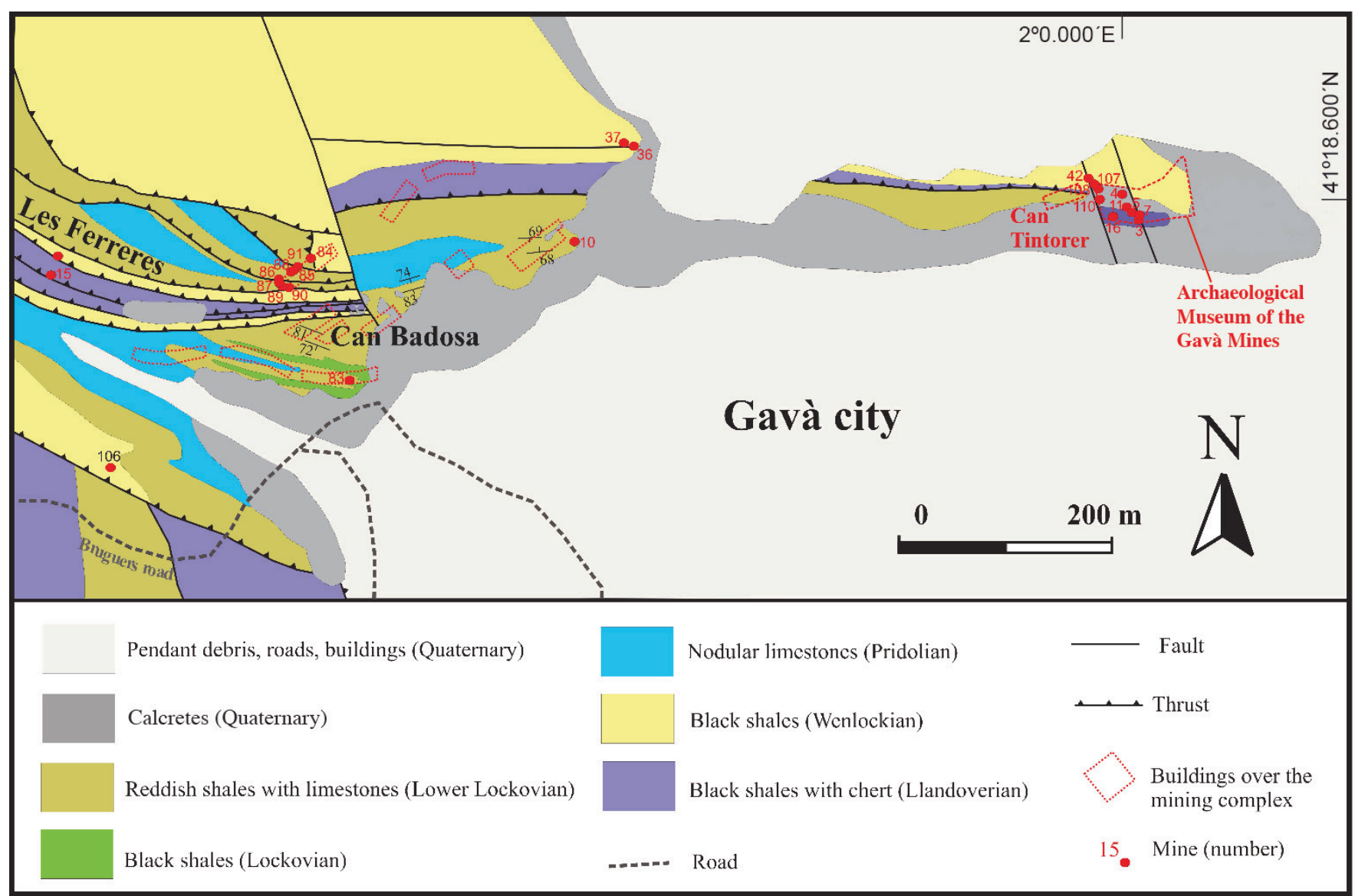

Figure 3 Geological map of the study area, with the distribution of Neolithic mines. 
black shales of Llandoverian age (nearly $100 \mathrm{~m}$ thick), interbedded with volcanic rocks and chertrich beds that can be locally up to $3 \mathrm{~m}$ thick. A Wenlockian unit consists of nearly $50 \mathrm{~m}$ of black shales with interbedded thin quartzite layers, and is overlain by $50 \mathrm{~m}$ of black shales of Ludlowian age that include some interbedded lenses of limestones towards the top. Thin layers of fluorapatite (from $1 \mathrm{~mm}$ to $10 \mathrm{~cm}$ thick) can be found within all the Silurian units, and pyrite is also commonly widespread as disseminated crystals. The series continues upward with a thick (30-40 m) unit of nodular limestones of Pridolian age, partially dolomitized or ankeritized (La Creu Formation; Julivert et al., 1985). The overlying Olorda unit consists of a thin (2-3 m thick, lower Lochkovian) layer of black schists overhead by interbedded limestones and reddish shales (middle Lochkovian), green to bluish marls with carbonate nodules (15-20 m thick, upper Lochkovian), limestones alternating with marls (10-15 m, Pragian), and green marls at the top. Carboniferous materials are poorly represented in the Gavà area, and consist of some dark bedded radiolarites ("lydites"), greenish shales, and greywackes that might correspond to the Tournaisian and Visean (Anadón et al., 1983).

The Paleozoic series has been affected by two stages of Hercynian deformation with (1) NW-SE folds with opposite vergence, and (2) SW-dipping axial surface folds. Both fold generations have associated thrusts in their flanks, and the Silurian black shales act as the detachment level for these thrusts. The Hercynian deformation was accompanied by very low-grade metamorphism. Intrusive igneous rocks are absent in the study area. Hydrothermal circulation along the Hercynian thrusts and associated structures produced a general dolomitization and ankeritization of the Silurian-Devonian limestones.

Towards the SW part of the study area, the deformed Paleozoic series is unconformably covered by a thick sequence (more than $100 \mathrm{~m}$ ) of Early Triassic Buntsandstein red conglomerates and sandstones (Virgili, 1958). The Triassic series continues with an ensemble of lower Muschelkalk transgressive limestones and dolomites (Calvet and Ramon, 1987), overlain by regressive red clays and gypsum (middle Muschelkalk facies; Morad et al., 1995) and finally by limestones, dolostones, and marls of the upper Muschelkalk facies (Calvet et al., 1987). The Jurassic and Cretaceous sedimentation are represented by the thick limestone series of the Garraf basin (Salas, 1987; Albrich et al., 2006).

The basement-cover ensemble is crosscut by NESW- and NW-SE-striking fault systems that were generated during the Alpine orogeny and have associated fault breccias and fault gauges (Guimerà, 1984). These faults define also the horst and the late Neogene-early Quaternary coastline and, later, the contact with the Pleistocene-Holocene deltaic materials of the Llobregat River plain.

The Pleistocene-Holocene erosion shaped a landscape that is characterized by smooth hills with Paleozoic rocks (Gaspar-Escribano et al., 2004). There is evidence of a weathering period during the lower Pleistocene, which produced strong changes in the outcropping basement. First, the pyrite-bearing black shales were oxidized; the resulting acidic and oxidizing fluids interacted with the shales and removed the organic matter. This process generated the discoloration of Silurian black shales, which became pale grey, as well as the development of sulfates like jarosite and alunite. Dating of such alunite from Gavà yielded aK-Ar ageat $1.20 \pm 0.05 \mathrm{Ma}$, and alunite in a similar assemblage from Montcada i Reixac yielded aK-Ar ageat $1.33 \pm 0.05 \mathrm{Ma}$ (Calabrian; Camprubí et al., 2003). These ages correspond to the formation of variscite, closely associated with the alunite. The weathered domain extends up to 10-20 meters below the unconformity between the Silurian shales and the Quaternary cover. In addition, this alteration led to the development of karstic ferruginous ores on the Silurian-Devonian ankeritized limestones (Costa et al., 1993).

The Paleozoic materials in the lowest part of these hills are unconformably covered by Quaternary sediments. The Quaternary cover generally starts 
at the bottom by creamy calcretes, up to $2 \mathrm{~m}$ thick, that may grade vertically to reddish clays with carbonate nodules (up to $2 \mathrm{~m}$ thick), unconsolidated breccias with a red clay matrix (up to $3 \mathrm{~m}$ thick), brownish paleosoils (up to $2 \mathrm{~m}$ thick), and finally reddish-brown clays (up to $2 \mathrm{~m}$ thick), which used to be covered by anthropogenic sediments. This sequence is similar to that found in many areas of the Quaternary of the Barcelona-Llobregat domain, the so called "tricycle," which corresponds to humid and warm edaphic episodes (i.e., Solé Benet et al., 1988; Casassas and Riba, 1992; Riba and Colombo, 2009). To the SE, the Llobregat delta plain consists of deposits of river terraces, flood plain facies, and Pleistocene-Holocene paleochannels (Daura et al., 2013).

\section{Styles of phosphate mineralization in the Gavà Neolithic Mining Complex}

Variscite, other phosphates, and minerals of the alunite supergroup (APS) occur only in the Paleozoic basement (Mata-Perelló et al., 1983; Gimeno et al., 1995). The following types of phosphate mineralization have been distinguished (Costa et al., 1993; Camprubí et al., 1994, 2003):

a) Primary synsedimentary fluorapatite thin beds ( $1 \mathrm{~mm}$ to $2 \mathrm{~cm}$ thick) or nodules (spherical or flattened bodies of $1-3 \mathrm{~cm}$ in diameter, occasionally produced by boudinage of the apatite beds in the flanks of Hercynian folds). Fluorapatite occurs as grayish to black cryptocrystalline radial groups. These phosphates are interbedded within the Silurian black shales and therefore were affected by all the deformation episodes described above.

b) Strata-bound variscite and APS phosphates that replace the above primary stratiform deposits. This replacement occurs only in the weathered profile domain (grayish shales), and may be complete or only partial along the border of the beds or neighboring cracks. Black phosphosiderite, dark reddish strengite or yellowish aluminian strengite accompanied with jarosite and alunite are the dominant phosphates in the uppermost weather- ing profile domain (up to $4 \mathrm{~m}$ in depth), yellowish green ferrian variscite is common at intermediate depths (4-8 m) and gemmy green variscite occurs mainly at the bottom of the weathering profile (8-15 m).

c) Subvertical variscite and APS phosphate veinlets. They are restricted to the weathered part of the profile. These are generally thin $(1 \mathrm{~mm}$ to 2 $\mathrm{cm}$ ) and occur as joint linings. There is a vertical zoning of the infilling minerals, similar to the one observed in the replaced synsedimentary phosphates: in the upper domain (up to $4 \mathrm{~m}$ in depth) alunite or jarosite, aluminian strengite and cuprian crandallite are found; yellowish green ferrian variscite is typically found at the intermediate domain (4-8 m), whereas the apple green to bluish variscite is found at the lower domains. The unweathered black shales do not contain phosphate veinlets.

d) Strata-bound Ca- and Fe-rich phosphates such as tinticite, montgomeryite, calcioferrite, hydroxylapatite, and dufrenite occur in veinlets or nodules. They are commonly associated with goethite, alunite, jarosite, and secondary carbonates. These "secondary" phosphates are probably generated when the weathering affects the ankeritized or dolomitized limestones, and marls overthrusted by the phosphate-bearing black shales.

The deposits of "secondary" phosphates are usually unconformably covered by Quaternary calcretes, rarely by red clays, or maybe eventually found in surface exposures.

Pe-Piper and Dolansky (2005) suggested that the occurrence of APS minerals is a good proxy to the existence of acidic and oxidizing solutions in association with APS minerals precipitation. Therefore, the genesis of the variscite mineralization in the Gavà area and in similar deposits along the CCR can be explained as a result of the weathering of the phosphate layers interbedded within the Silurian pyrite-rich black shales. The resulting acidic fluids leached phosphate and aluminum from the host rocks, necessary to produce secondary Al-rich minerals such as variscite, crandallite, alunite, and jarosite. The Al-phosphates were 

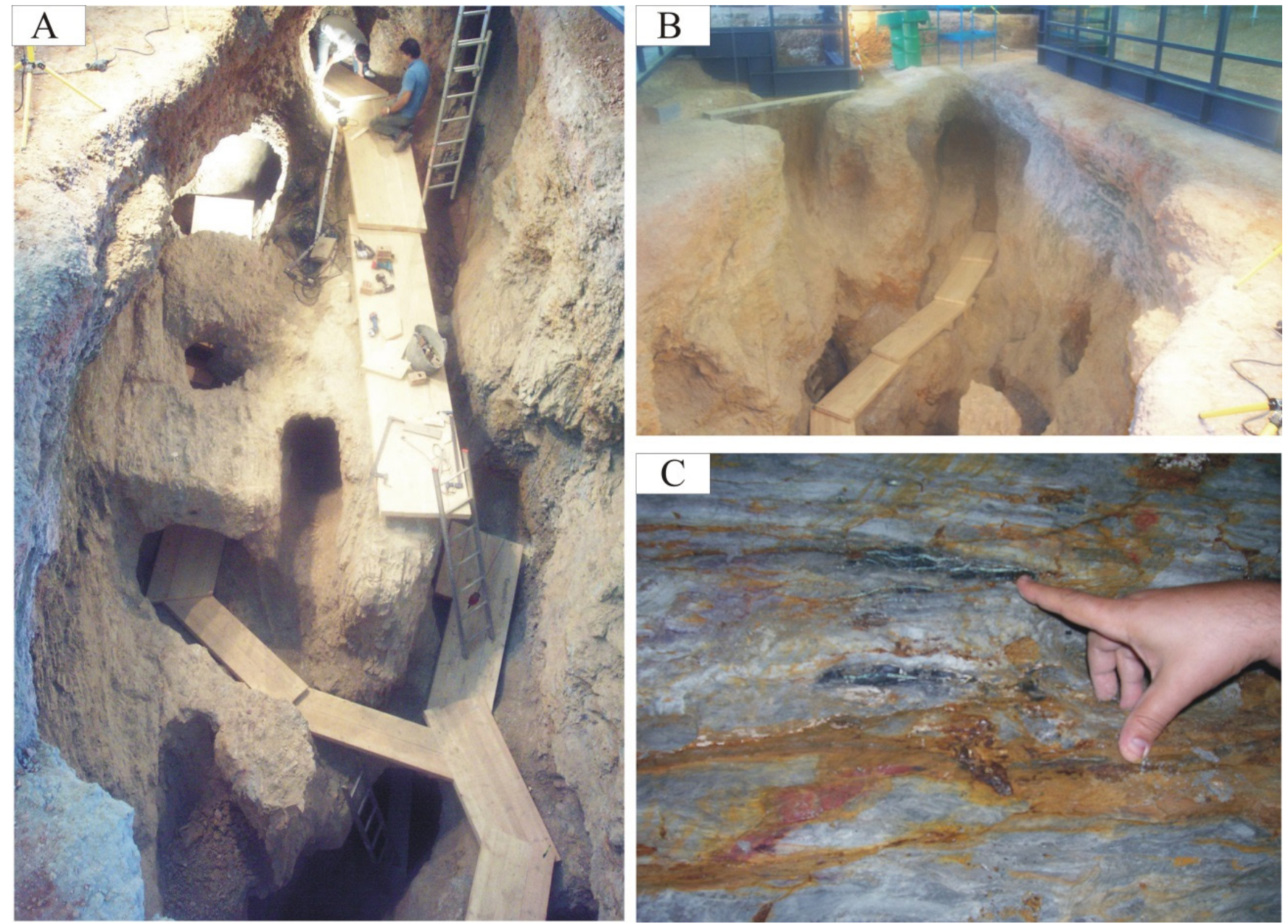

Figure 4 (A) General view of the central cavity of the ensemble of mines 3, 5, 7, and 11, from the surface towards the WNW. (B) View of the mine complex from the opposite side of the cavity, towards the ESE. (C) Detail of variscite veinlets (green) within phosphosiderite layers (black) hosted by weathered Silurian shales (gray).

formed by direct replacement of the apatite beds or by precipitation in veins along the weathering profile. Similar processes have been invoked to explain the genesis of APS concentrations in recent paleosurfaces in Sudan (Dill et al., 1991) or in the basement below the Permo-Triassic weathering profile in the Iberian Ranges (Borruel-Abadía et al., 2016). In addition, APS minerals were also formed by diagenetic processes in the Triassic cover (Galán-Abellán et al., 2013). Thus, when the P-rich acidic fluids reached the Silurian-Devonian carbonates they produced $\mathrm{Ca}$ - and Fe-rich phosphates, such as apatite, strengite, dufrenite, tintic- ite, and calcioferrite (Costa et al., 1993), and were accompanied by the formation of large amounts of "secondary" Fe oxides and hydroxides.

\section{Distribution of mining operations in the Gavà area}

The archaeological excavations in the study area, which were indirectly (and unintentionally) helped by the urban development in the last decades of the 20th century, have unraveled more than 100 old mines in the area. The archaeological excava- 
tions in most of these mines were followed by their geological mapping, which led to the identification of the extracted material and the host rocks. Two different main types of mining operations can be recognized in the area: (1) iron mines, which correspond initially to the Iberian and Roman period sand were intermittently exploited until the 20th century (Díaz-Acha et al., 2019), and (2) variscite mines, Neolithic in age, and several are found near each other.

The Neolithic mines consist of shafts with variable complexity, trenches, or tunnels dug into the Silurian gray shales and crosscutting, in many cases, the overlying Quaternary sediments. Fifty-four Neolithic mining operations of this type have been discovered (Figure 3). However, most of the preserved mines are found in a $30000 \mathrm{~m}^{2}$ area around Can Tintorer, which is by far the largest known Neolithic mining complex in the Gavà area (Figure 3). The Can Tintorer area is located on a plain near the foot of Les Ferreres range, where the Quaternary cover may achieve several meters in thickness, covering Paleozoic outcrops. Another significant group of mines is located in the Can Badosa-Les Ferreres area, in the middle part of the Les Ferreres range. In the latter there is no Quaternary cover on the Paleozoic rocks, and, consequently, variscite and other phosphate occurrences are found in surface exposures.

\section{Description of the mining operations}

The geology of mines 1, 2, and 8 was already described in detail by Costa et al. (1994) and Camprubí et al. (2003). Therefore, the present work is focused on more recent archaeological excavations of the Neolithic mines. The mines have been developed in two different stages: (a) completion of the excavation of the galleries discovered in the 1970s, and (b) exploring new galleries that were discovered during new housing development in the Can Badosa-Les Ferreres area.

\subsection{MINES 3, 5, 7, AND 11 (CAN TINTORER AREA)}

The excavation of mines $3,5,7$, and 11 , which were initially considered to be individual mines, showed that they were in fact connected at depth and can consequently be considered a single mine. These are the most complex excavated mines in the Gavà area, and their continuity at depth could be even greater, as some of the internal galleries collapsed and others have not yet been excavated. The excavated exploitations consist of a large cavity connected to a complex system of galleries and mine shafts (figures 4A and 4B). All the mining operations were developed into the Ludlowian grey shales and the overlying Quaternary calcretes. Variscite is visible in situ in most of the galleries and pits (Figure 4C).

The large central cavity (labeled A in Figure 5) has an elliptical shape, is oriented roughly $\mathrm{E}-\mathrm{W}$, and is limited by vertical walls (3-5 m deep with respect to the present-day surface). The original surface of the cavity walls was clearly covered by Quaternary calcrete. Some walls show evidence of having been developed after older vertical shafts. This cavity is connected to several shafts open in the vicinity by tunnels underground; however, most of the galleries, trenches, and shafts appear to be developed from the cavity A.

Up to eight levels of exploitation have been recognized in this mine. Their vertical spacing generally ranges between 0.5 and $3 \mathrm{~m}$, and it can be less than $25 \mathrm{~cm}$. The levels of exploitation were generally connected by shafts and exceptionally by ramps. Most of the galleries are horizontal, and most of the galleries and shafts are excavated following the variscite mineralization and associated minerals. Yet, some tunnel slack such mineralization, such as tunnel B (see Figure 5). This mine is the deepest one in the mining complex, which allows visualization of the vertical zoning in the variscite mineralized structures; the variscite with the brightest colors have been found at the deepest levels of the mine. Variscite is notably abundant 


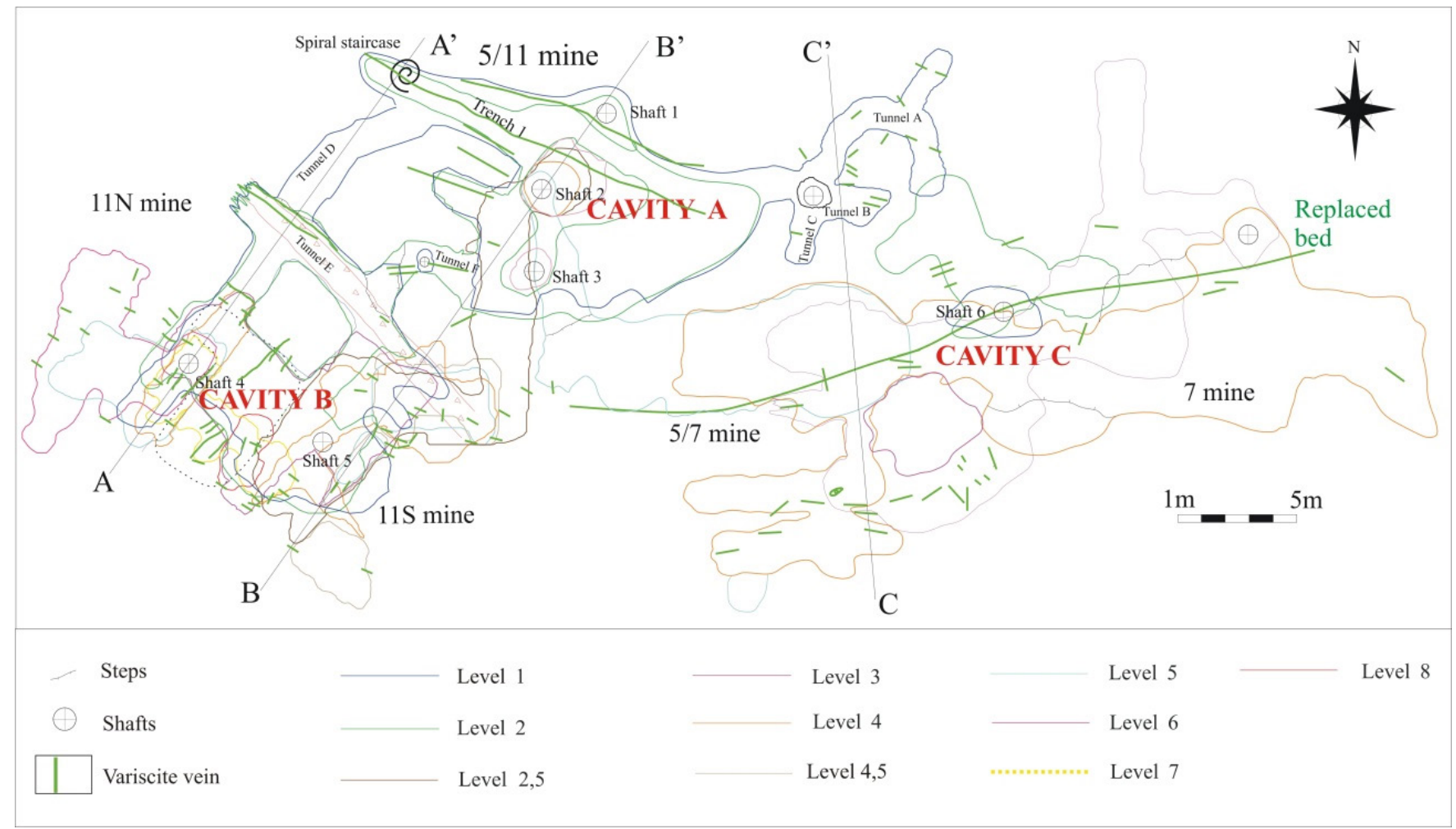

Figure 5 General map of the works in the complex formed by mines 3, 11, 5, and 7, with the indication of some variscite veins. The position of the sections shown in figures 6 to 8 is also indicated.

in most of the galleries and pits, as can be seen in end cuts, tops and bottoms of the stopes, pits and galleries used for exploitation, as well as many pillars. The mineralization occurs mainly as variscite or strengite veins, although some strata-bound variscite is also found.

In order to better describe the system of exploitation, we have divided the mine in different cavities (Figure 5). Cavity A contains high-quality greenish-blue variscite in vertical veinlets that roughly strike $\mathrm{E}-\mathrm{W}$. The distribution pattern of the veinlets rules the exploitations geometry. The variscite veinlets usually range between $2 \mathrm{~mm}$ and $1 \mathrm{~cm}$, and can be up to $3 \mathrm{~cm}$ thick, which provide large enough fragments to be crafted as beads. Relatively thick and continuous veins occur in trench 1 and in some shaft walls, especially the shaft 1 , which is crosscut by the main cavity. Some of these veins were tracked by galleries and stopes in the underlying levels and are accessed through 1.5 to $3 \mathrm{~m}$ long vertical shafts. In addition, some short exploration tunnels start from the main cavity and follow thin vertical green variscite veinlets, as in the case of the tunnels A, B, C, and D (Figure 5). Tunnel A constitutes the uppermost level in the mine, but it would be unlikely older than cavity A. In tunnel $\mathrm{A}$, itis possible to distinguish associated exploration galleries crossing in different directions and aiming at several vertical veins containing greenish clay minerals that resemble variscite. However, such clay minerals are too soft to be used to produce ornaments and therefore these galleries were abandoned.

Also, the miners dug stope D (Figure 6) through barren shales that connect with an exploration gallery $(\mathrm{E})$ that follows greenish clays and small variscite veinlets. Gallery E continues a few meters towards the SE, and has a NW branch that has not been completely excavated. These galleries follow a fault breccia that strikes NW-SE, probably associated with the Alpine orogeny. The target material in this gallery was mainly greenish clay 


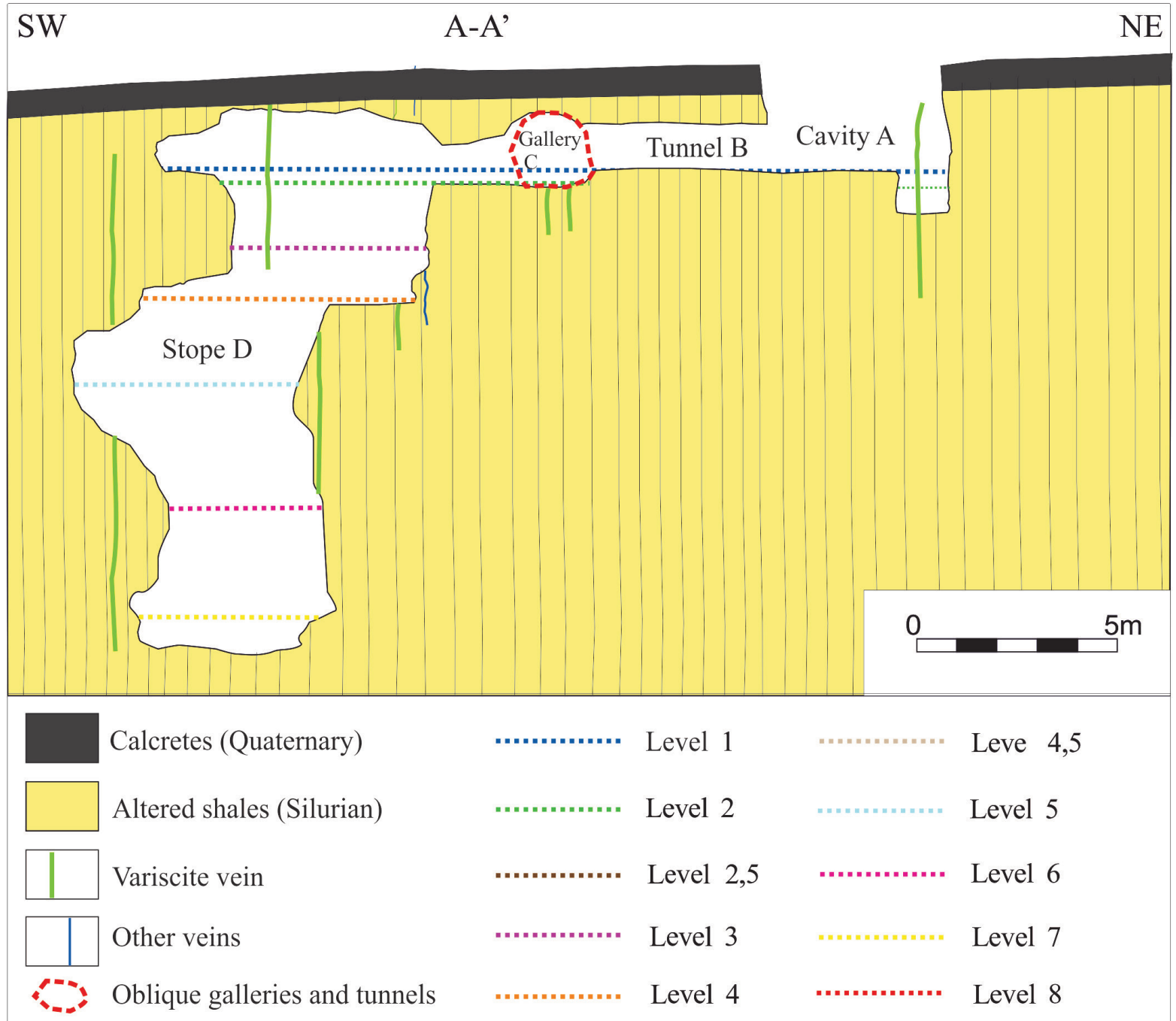

Figure 6 Geological section along A-A' in Figure 5, with Neolithic mining works and mineralized veins indicated therein. The position of the mining levels is also indicated.

minerals, similar to those found in gallery $\mathrm{A}$, in the form of numerous mm-wide subvertical veinlets. Finally, this gallery communicates with cavity A by means of gallery $\mathrm{F}$, which was used for the extraction of variscite from veinlets.

The prolongation of gallery D towards the SW changes slightly in direction following strengite and ochreous jarosite veins and then gives access to a large closed tunnel (labeled B in Figure 6). This cavity achieves the deepest point in the mine $(15 \mathrm{~m})$. It follows numerous subvertical variscite veinlets that strike $\mathrm{E}-\mathrm{W}$ and $\mathrm{N}-\mathrm{S}$, being the top of the cavities about 2 to $3 \mathrm{~m}$ above stope $\mathrm{D}$ entrance
(Figure 6). The veins follow all types of discontinuities, mainly the foliation of tight folds and joints, but in some cases the variscite mineralization can be strata-bound. Hence, there is a large density of phosphate veins in this sector, which are continuous for several meters. This arrangement allowed the miners to exploit these veins by an ensemble of parallel and perpendicular stopes separated by rock pillars (Figure 5). The $\mathrm{B}^{-} \mathrm{B}^{\prime}$ section (Figure 7), which is located in sector A, also shows types of exploitation that follow mineralized veins. At the NE part of this sector some galleries and pits were communicated only by small holes $(10-20$ 
$\mathrm{cm}$ in diameter), a space clearly unable to permit the passage of the miners. Some of the galleries were separated from other levels only by a few centimeters of rock, thus resulting in a high risk of collapse.

Cavities A and $\mathrm{C}$ are communicated at depth by another complex system of galleries, all of them exploited following the network of variscite veinlets. Large stopes are found again in areas $\mathrm{E}$ and $\mathrm{F}$, and remnants of subvertical variscite veins up to $1 \mathrm{~cm}$ thick can be observed in the fronts of these stopes (Figure 8).

Inside the mine, many different archaeological remains were found, even though burials were absent in this case. The mine 7 was dated at 2360 BC using ${ }^{14} \mathrm{C}$ from charcoal (Villalba et al., 1986).

\subsection{MINE 16 (GAN TINTORER AREA)}

Mine 16 has not been completely excavated and, therefore, its possible links with other mines is not yet established. Its provisional mapping suggests that it cannot be connected with the neighboring mines 7 and 11 . Mine 16 starts with a shaft plunging 50/030 that first passes across $2.5 \mathrm{~m}$ of a slightly dipping reddish Quaternary calcrete and continues $3.5 \mathrm{~m}$ on subvertical lower Silurian grayish chert and shales that are widely altered (Figure 9). Then the plunging changes to $45 / 290$ in the same folded Paleozoic rock assemblage. A 5 $\mathrm{m}$ long gallery, not completely excavated by modern archeologists, is located at the bottom of this shaft and plunges 10/024. This gallery follows thin

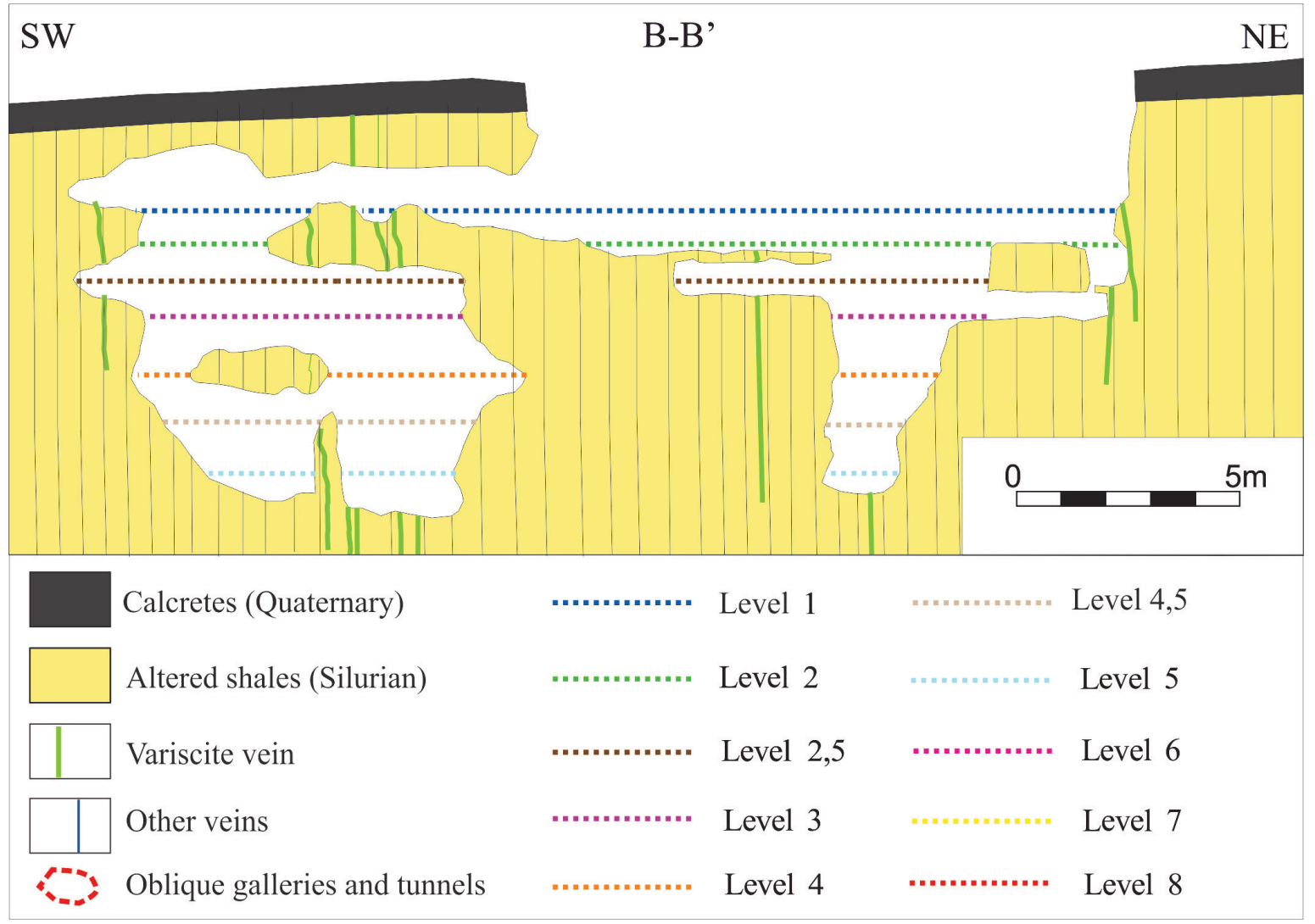

Figure 7 Geological section along B-B' in Figure 5, with Neolithic mining works and mineralized veins indicated therein. The position of the levels is also indicated. 


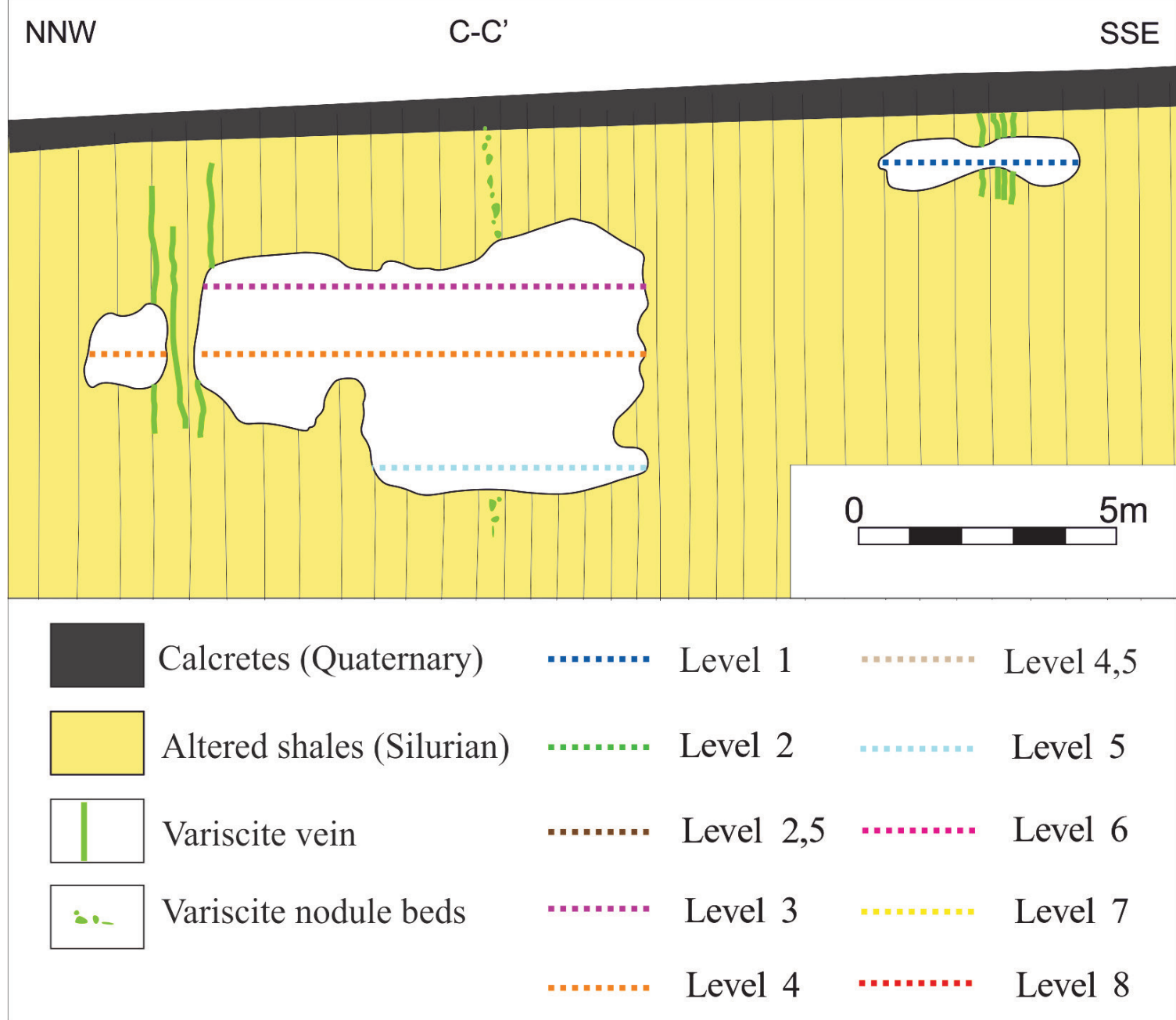

Figure 8 Geological section along C-C' in Figure 5, with Neolithic mining works and mineralized veins and layers or nodules indicated therein. The position of the mining levels is also indicated.

subvertical greenish variscite and reddish strengite veinlets, and cuts some small fluorapatite levels replaced by variscite. The mine was filled with detrital sediments and contained many archaeological artifacts, among which stands out the well-known Gavà Venus (Bosch, 2010). The mine was dated as $5190 \pm 40$ B Pusing ${ }^{14} \mathrm{C}$ from charcoal (Bosch, 2010).

\subsection{MINE 42 (GAN TINTORER AREA)}

Mine 42 is located at the NW corner of the Archaeological Museum of the Gavà Mines building, and the gallery roof was partially removed during the placement of the building foundations. Also, the mine entrance is not conserved and there are only some remnants of the bottom of the mine. The galleries were very superficial, less than $1.5 \mathrm{~m}$ deep, as indicated by joints lined by calcrete. This also suggests that this mine was originally excavated in calcrete. The preserved part of the mine follows an $\mathrm{E}-\mathrm{W}$ direction, is about $5 \mathrm{~m}$ long, and is completely hosted by Ludlovian folded gray shales. There are thin brownish strengite veinlets with the same orientation as the mine, thus indicating that the gallery was excavated following such veins. No archaeological material was found inside this mine and no chronological information is available. 


\subsection{MINE 110 (GAN TINTORER AREA)}

Mine 110 is near the NW corner of the Museum building, and the upper half of the galleries was destroyed when preparing the foundations of this building. The deep part of the mine is not completely excavated and may be connected with mine 2. A reconstruction of the preserved galleries suggests that after the entrance (probably by a short shaft, less than $2 \mathrm{~m}$ in depth) a gallery with a round section and about $1.5 \mathrm{~m}$ in diameter has a SW direction for $3 \mathrm{~m}$, and then has a SE direction for $3 \mathrm{~m}$ more. After that, the gallery branches out towards the SW (for $2 \mathrm{~m}$ ) and towards the $\mathrm{S}$ (not excavated). These two last galleries follow thin subvertical yellowish green variscite veinlets. The ensemble of galleries plunges $10^{\circ} \mathrm{SSE}$. No archaeological material was found inside this mine and no chronological information is available.

\subsection{MINE 83 (GAN BADOSA-LES FERRERES AREA)}

Mine 83 is located at the foot of the Les Ferreres Range, NW of Gavà. It was discovered during the excavation for the foundations of a nearby building. Unfortunately, the mine roof was destroyed but it has been possible to reconstruct the morphology of the mine (Figure 10). The mining development can be easily established considering that this mine has a sole entrance, by means of a 2 m-long pit. This entrance was dug in an outcrop of weathered phosphate beds (up to $10 \mathrm{~cm}$ thick) interbedded with Lochkovian grayish shales, near the contact with alternating reddish shales and limestones of the middle Lochkovian. The phosphate beds consist of black cryptocrystalline phosphosiderite $\left(\mathrm{FePO}_{4} \cdot 2 \mathrm{H}_{2} \mathrm{O}\right.$, a mineral of the metavariscite group). This set of geologicalmaterials is strongly affected by Hercynian chevron-style folding of the second phase of deformation (Melgarejo et al., 2009). From its entrance the mine continues to follow the phosphosiderite bed along two horizontal galleries: one towards the $\mathrm{SE}$ (2 $\mathrm{m}$ long), and the other towards the $\mathrm{N}$ (3 m long) that after a short step bifurcates into two galleries, one towards the

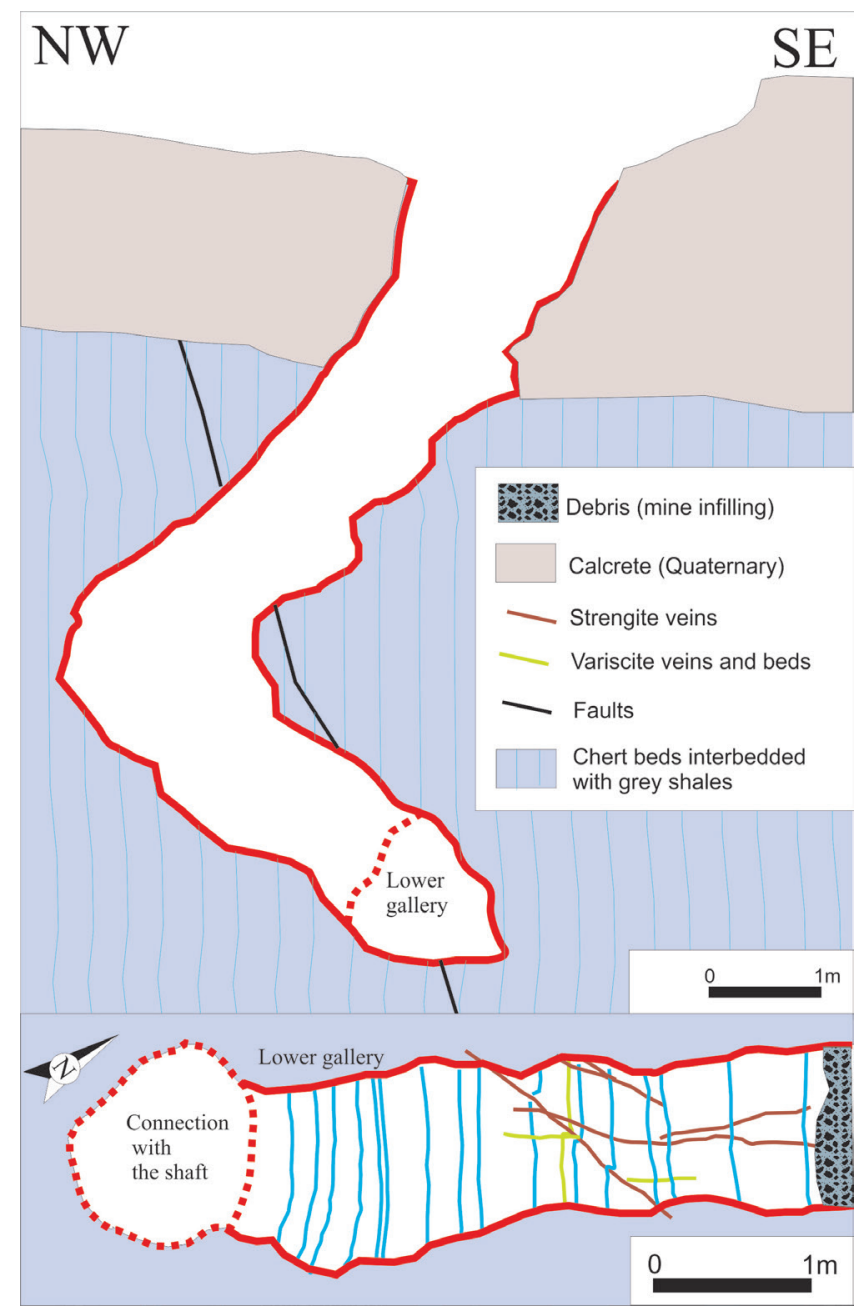

Figure 9 Top: Geological profile along the shaft of mine 16, with Neolithic mining works indicated in red. Bottom: Floor plan of the lower gallery, showing phosphate veins and levels.

W (4 m long) and the other towards the NE (3m long). The mine does not contain variscite, but white apatite occurs in some vertical thin veinlets (less than $2 \mathrm{~mm}$ thick). The mine was recycled as a grave and a large conglomerate stone was used to seal the entrance. The burial site contained archaeological material (Bosch et al., 2009). The mine is dated at $5220 \pm 110 \mathrm{BP}$ using radiocarbon in coal (Borrell et al., 2009).

\subsection{MINE 84 (GAN BADOSA-LES FERRERES DOMAIN)}

The site of mine 84 is at the Can Badosa neighborhood at the lower part of the Les Ferreres range, 
NW of Gavà. The mine has a relatively simple structure and consists of an exploration gallery (labeled gallery A in Figure 11) and an exploitation gallery (gallery B in Figure 11). The only entrance is a NE-SW ramp dipping around $25^{\circ}$ following an outcrop of black phosphosiderite that replaces $1 \mathrm{~cm}$ thick apatite beds (Figure 12). After $10 \mathrm{~m}$, gallery A finds a back thrust in the Lochkovian red shales with limestones. At this point the mine has two steps of about $1 \mathrm{~m}$ each towards the SW that follow the gray shales, probably because the miners recognized that multicolored shales and dolostones were devoid of phosphates, and started two new galleries (2A and 2B in Figure 11 ) towards the NW and SE (10 m long each) that follow small NW-SE striking variscite veinlets. These veins occur close to phosphosiderite beds and opal nodules (figures 11 and 12). These veins were thin (less than $4 \mathrm{~mm}$ thick) and therefore the mine probably failed to supply good quality variscite and was consequently closed and recycled as a sepulchral camera whose entrance was sealed with a large block of Pridolian limestone. The mine is dated at $4960 \pm 40$ BP by means of radiocarbon from coal (Borrell et al., 2009).

\subsection{MINE 90 (GAN BADOSA-LES FERRERES DOMAIN)}

Mine 90 was open in the Can Badosa neighborhood in the Les Ferreres range, but the access was destroyed by excavation for the foundations of a modern building. However, the position and the direction of the final section of the gallery of the mine (less than $1.5 \mathrm{~m}$ ) suggests that it would have consisted of a short shaft (less than $3 \mathrm{~m}$ long) and a short gallery (less than $3 \mathrm{~m}$ long). The mine follows a $60^{\circ}$ dipping thin veinlet (less than $2 \mathrm{~mm}$ ) of dark reddish strengite (Melgarejo et al., 2009). Abundant similar strengite veinlets cropped out at the bottom of the foundations of the building nearby and probably occurred in surface exposures because no Quaternary cover is found in this area. These veinlets were probably recognized in mines 86, 87, 88, 89, and 91.Thosemines were unfortu- nately destroyed during building operations. Mine 90 is dated at $5000 \pm 40 \mathrm{BP}$ by means of radiocarbon in coal (Borrell et al., 2009).

\subsection{MINE 15 (GAN BADOSA-LES FERRERES DOMAIN)}

Mine 15 consists of a short tunnel (less than 5 $\mathrm{m}$ long) opened in the flank of the Les Ferreres range, NW of Gavà. The tunnel is horizontal and has an approximate circular section, around 1.5 $\mathrm{m}$ in diameter, and follows small outcrops of yellowish ferrous variscite (up to $1 \mathrm{~cm}$ thick). The variscite is accompanied by thin veinlets (less than 2 mm thick) of pale greenish cryptocrystalline crusts of secondary phosphates such as montgomeryite $\left[\mathrm{Ca}_{4} \mathrm{MgAl}_{4}\left(\mathrm{PO}_{4}\right)_{6}(\mathrm{OH})_{4} \cdot 12 \mathrm{H}_{2} \mathrm{O}\right]$, calcioferrite $\left[\mathrm{Ca}_{2} \mathrm{Fe}_{2}^{3+}\left(\mathrm{PO}_{4}\right)_{3}(\mathrm{OH}) \cdot 7 \mathrm{H}_{2} \mathrm{O}\right]$, and white hydroxilapatite $\left[\mathrm{Ca}_{5}\left(\mathrm{PO}_{4}\right)_{3}(\mathrm{OH})\right]$ that are hosted by weathered Silurian grayish shales in the vicinity of the Silurian-Devonian limestones. These phosphate veins are visible in the adit. The tunnel was not refilled with sediments. No archaeological material was found inside this mine and no chronological information exists.

\section{Discussion}

The available data suggest that the Neolithic mines were generally opened in the weathered Silurian gray shales. In consequence, shafts and tunnels might have been unstable because Silurian rocks were intensely cleavaged and weathered and have enhancee gallery collapse, especially during rainy seasons.

However, in some cases, mines were also initiated in the unconformably overlying calcretes, those are harder and more compact than the Silurian shales. The shafts opened in calcretes would have protected the intricate mine works and also would have stabilized the mine entrance.

In addition, shafts and ramps that were dug on the hard Quaternary cover suggest that some of the mines were opened just following a mineral- 


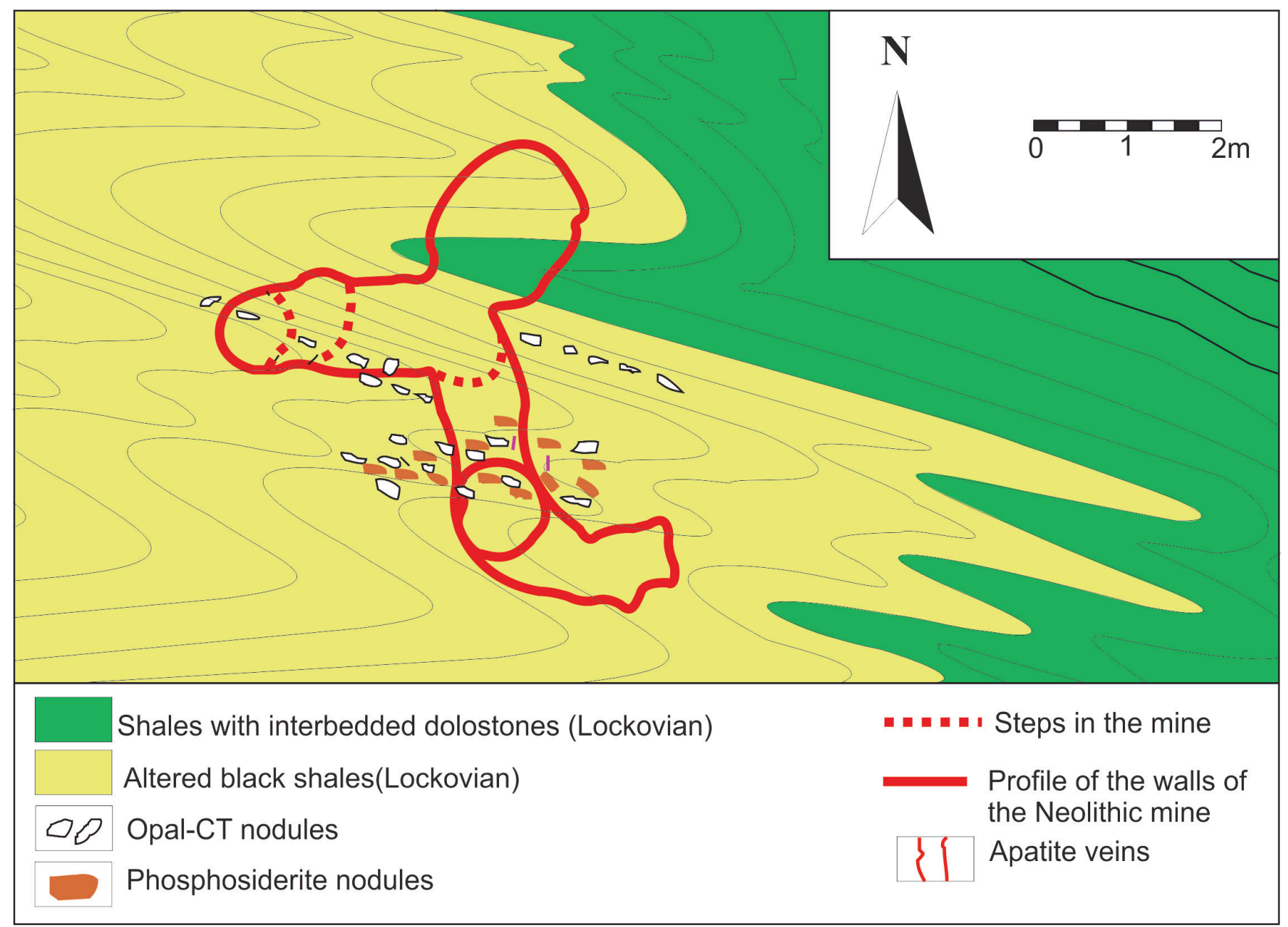

Figure 10 Topography and geological map of mine 83, showing the distribution of the mineralized units. Modified after Melgarejo et al. (2009).

ized outcrop. A possible explanation for such features, especially in complex mines that have not been completely excavated so far, could be that their original access entrance has not yet been discovered. According to this hypothesis, the original entrance could have been opened following a variscite outcrop, and the shafts would have been opened from the inside of the mine to the outside in order to create a ventilation system or emergency exit, or for fast transfer to the surface of extracted material. Nevertheless, some shafts have no communication whatsoever with any galleries, as is the case of mines 4 and 16. Consequently, it is likely that the Neolithic miners eventually understood that veins occur underneath the barren calcrete.

The mineral exploration systems seem to be diverse. Mine 11 could have been dug following variscite subvertical veins, as perhaps happened in shaft 1 at cavity A (Figure 5). Also, mine 84 can be interpreted as a result of reconnaissance survey following the phosphosiderite units, as it consists of an access shaft that follows an outcropping subvertical mineralized layer and two exploration galleries follow the phosphate beds. The hypothesis of this mine being used as a reconnaissance survey 
stems from the fact that phosphosiderite has not been found in Neolithic beads, and therefore this mine did not actually produce any valuable material. A similar interpretation can be made for mine 84. It would then turn out that the Neolithic miners would have recognized that phosphosiderite and variscite were found in the same mineralized structures and that one could eventually lead to the other. In other words, it encapsulates the concept of mineral association. The use of such concept for exploratory purposes could be extended to other minerals besides phosphosiderite, a practice that could have been turned into a routine in exploration and that is still successfully used today. The entrance to mines may be through (1) a vertical shaft, as in mines 7, 11, and 16; (2) a ramp, as in mine 84; or (3) a tunnel, as in mine 15. The type of access depends on the orientation of variscite mineralization in outcrops and the existing relief conditions. Ramps were developed directly on outcrops of slightly dipping phosphate beds, as in mine 83 where the mine follows a replaced phosphate bed dipping to the SW. However, in the outcrop variscite is absent and the ramp clearly follows strata-bound phosphosiderite mineralization as replacements after apatite beds.

There is no evidence for exploitation of any minerals other than variscite. Significant mining operations were not carried out on opal-CT nodule horizons, not even when mining operations crossed such layers. However, at least in mine 84, there is evidence that the miners excavated small pits on such nodules, probably to produce tools for exploitation of the mine.

The mines in the Can Badosa-Les Ferreres area consist of a single access (shafts, ramps, or tunnels) and galleries of exploitation were developed once the mineral was found, which is a relatively simple method. However, the mining and exploration techniques in the Can Tintorer area are much more complex than that. The occurrence of tunnels and galleries, with or without variscite in them, suggests that some of them were used as exploration galleries, as is the case of gallery B. Once a mineralized vein was found, as is the case of tunnel $\mathrm{C}$, the galleries progressed following the vein or, in some cases, the vein was exploited intensively, thus producing large stopes. In the case of stope B, at least its upper part was exploited by the system of overhand stoping, because the top of the stope is up to $3 \mathrm{~m}$ higher than the access galleries (very close to the surface), and there is no other access. Similarly to cavity A, the present day risk that the top of stope B may collapse, suggests that cavity A was produced by partial collapse of old mines after their intensive exploitation. Also, stope B is found below the topographic level of gallery B, which suggests that such mine works could have been carried out by underhand stoping. These mines make probably the oldest case for such systems of exploitation.

The stability of such complex mining structures relies in the remaining pillars, and the existence of unexploited mineralization in most of the pillars demonstrates that the Neolithic miners were aware of this need. In some cases, the galleries situated at different levels are communicated by small holes (too small to allow the passage of a person) that could have been used for ventilation.

The archaeo-anthropological analyses performed on the human bones found in the burial sites in mines 84 and 90 revealed injuries and malformations. This could be the result of the hard work conditions inside these mines (Casas and Majó, 2009) and that the persons buried in them could have been miners themselves. These burial sites contain variscite beads, which would imply that the miners were buried with ornaments that were crafted with the very same material that they extracted in life.

The tools used for the exploitation were very rudimentary: rocks were crushed with hornfels hammers and bone chisels, and mine walls would have been expanded by lighting fire on the surface and then inducing their quick cooling (Villalba and Edo, 1991). The variscite fragments were trimmed 


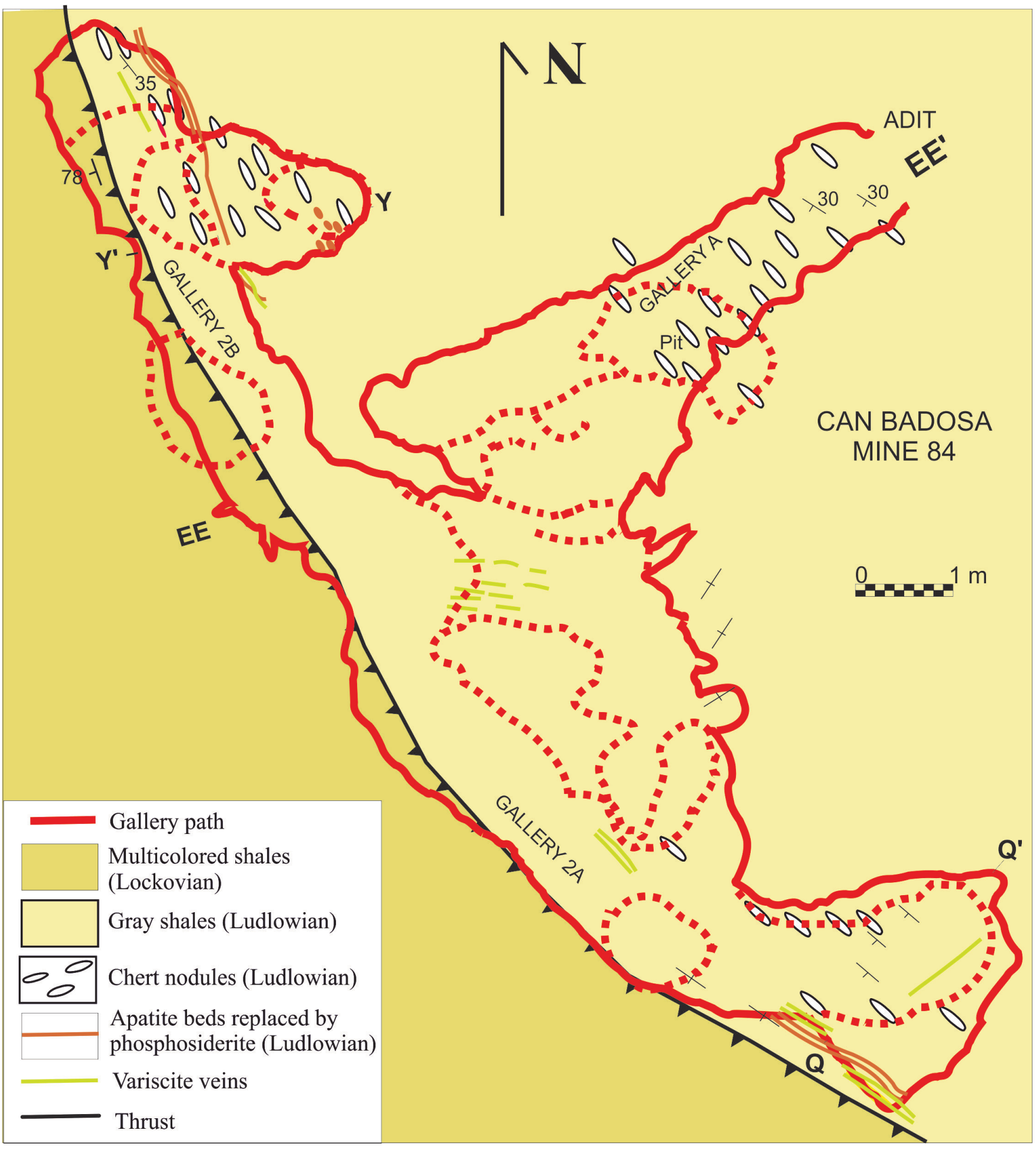

Figure 11 Topography and geological map of mine 84 at Can Badosa, showing the distribution of the mineralized units and the location of sections shown in Figure 12. Modified after Melgarejo et al. (2009). 
and polished up to the desired barrel shape and finally pierced using a drill (Edo et al., 1995; Noain, 1996).

In general, a typical operating mine consists on an extraction area, a processing plant where ore and gangue are separated, and an area to throw the rejected undesired material (dumps). In the case of Gavà the processing areas and the dumps have not been found, probably due to the erosion processes active during more than 5000 years. However, some concentrations of unprocessed variscite fragments were found near the entrance of mine 84, suggesting the existence of a processing area nearby (Borrell et al., 2005). Further, a large amount of pieces partly elaborated or rejected were found in the inner part of mine 85 (Borrell and Estrada, 2009; Borrell and Bosch, 2012; Borrell et al., 2015), suggesting that at least part of the elaboration of the beads could have been performed, in certain periods, inside this mine.

\section{Conclusions}

The aim for exploitation in the Gavà Neolithic Mining Complex was variscite that was formed during the Calabrian in a lateritic context by replacement of Silurian apatite beds, and by precipitation in fractures and veins due to the remobilization of phosphate and $\mathrm{Al}$ from the host rocks. Other minerals associated with variscite were not profited, but the occurrence of accompanying phosphates were used in the Les Ferreres sector as a criterion of exploration for new variscite deposits, as indicated by shafts and galleries opened in phosphosiderite mineralization. Therefore, the Les Ferreres mines were opened on the basis of previous mining operations that provided the necessary observations to infer mineralogical and geological criteria for exploration in other areas. Many of these operations were unsuccessful due to the complex tectonics of the area, which made the understanding of the continuity of mineralized structures very difficult. The common presence of mines that were initiated on the barren Quaternary calcrete deposits (instead of the weathered Silurian shales that host the mineralization) in all the sectors means that miners did not always start the mines following an outcropping deposit, and demonstrates that the Neolithic miners had some geometrical and practical understanding of the unconformity concept.

Most mineral operations in the Gavà area did not achieve more than $40 \mathrm{~m}$ in total length and consist of trenches or a combination of galleries, ramps, and shafts with only one underground level. These works do not contain variscite, or contain variscite of poor quality (too-thin veinlets or unappealing coloration), and therefore these mines can be interpreted as unsuccessful exploration works.

The successful mineral exploitations had more than $200 \mathrm{~m}$ in total length and reached up to 15 $\mathrm{m}$ in depth, and were abandoned once they were unable to produce material that met the desired quality. The mines are restricted to the weathered part of the host weathered Silurian shales and the water table at the time of Neolithic mining did not correspond with the deepest evidence for mining. The occurrence of different mineralization styles (strongly folded strata-bound NW-SE and subvertical veins - with various strikes) forced the Neolithic miners to build a complex system of galleries. Further, provided that the variscite with deeper green color (the highest quality material) tends to occur in the deepest part of the profile, the mines reached greater depths by means of steps, ramps, or shafts.

As mining progressed deeper and the network of galleries became more complex, the risk of collapse increased, the daylight dimmed, and the ventilation worsened. The first problem was addressed by means of the excavation of shafts on Quaternary calcrete, the exploitation by the systems of overhand and underhand stoping sus- 


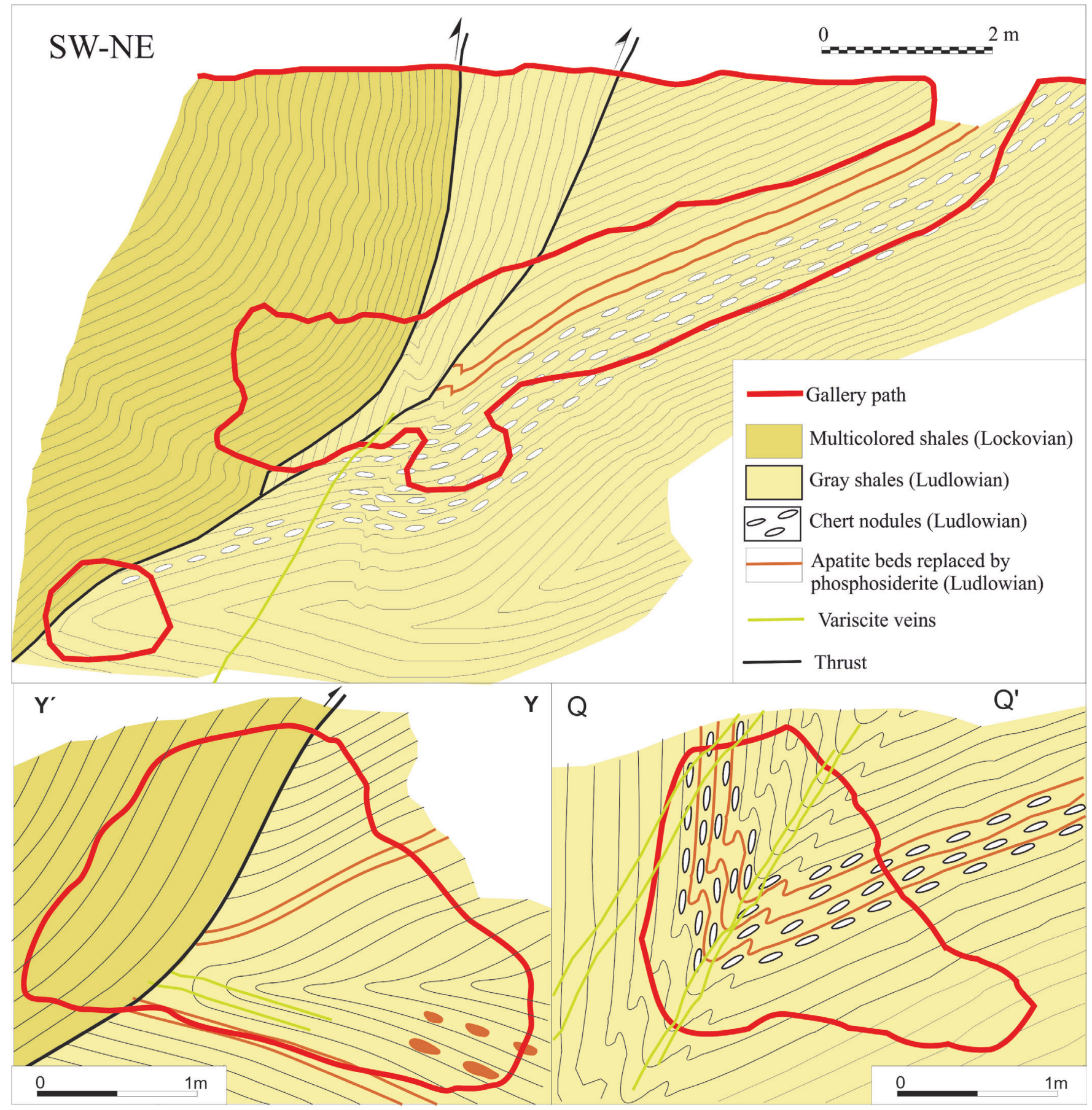

Figure 12 Geological sections of mine 84 at Can Badosa, showing the distribution of the mineralized areas. Modified after Melgarejo et al. (2009). The location of these sections is indicated in Figure 11. 
tained by pillars (probably the oldest example of this type of exploitation in history), and the refilling of the exploited galleries with rubble coming from other galleries and shafts. The use of some kind of lamps would be necessary to light up working fronts, but no evidence of light systems has been found. General ventilation in the mines was favored by opening new shafts or connecting different mining works. Some small holes that connect galleries at different levels are interpreted to have been dug with the purpose to improving air circulation.

Therefore, the Neolithic miners were not only able to construct complex stable galleries up to $15 \mathrm{~m}$ deep, but also to understand the geometric controls for mineralization, and designed their exploitation accordingly. This complex activity suggests a high degree of specialization for miners.

Deeper-colored variscite is still abundant in many fronts of the preserved mines. Therefore, the mines were not closed because they were exhausted, but other reasons must be found to explain why most active mines, as those of the Can Tintorer sector, were abandoned. Future archaeological works, together with geological studies, may be able to provide such valuable information.

\section{Acknowledgements}

This paper is a contribution to the projects 2014 SGR 1661 and 2014/100820 of the Generalitat de Catalunya, which provided the necessary funds. The Municipality of Gavà and the Gavà Museum helped in the study of the archaeological sites and the Environmental Department (in particular through Elisenda Miquel) helped with access to many areas in the municipality. Some of the samples used in this study were provided by the Mineralogy Collection of the University of Barcelona and by the Natural Sciences Museum of Barcelona. The authors acknowledge the revisions by the referee Dr. Oriol Oms Llobet and by the anonymous reviewers as well.

\section{References}

Acevedo, N., Weber, M., García-Casco, A., Proenza, J.A., Sáenz, J., Cardona, A., 2016, A first report of variscite in Tairona (A.D. 1100-1600) from the Sierra Nevada de Santa Marta, Colombia, and its implications for Precolumbian exchange networks in the region: Latin American Antiquity, 27(4), 549-560.

Albrich, S., Bernaus, J.M., Boix, G., Caus, E., Martín-Closas, C., Salas, R, Vicedo, V., Villalonga, R., 2006, Caracterización bioestratigráfica y paleoambiental del Cretácico inferior (BerriasienseBarremiense) del Macizo de Garraf (Cadena Costera Catalana): Revista Española de Micropaleontología, 38(2-3), 429-452.

Alonso, M., Edo, M., Gordo, L., Millán, M., Villalba, M.J., 1978, Explotación minera neolítica en Can Tintoré (Gavà, Barcelona): Pyrenae, 13-14, 7-14.

Anadón, P., Colombo, F., Esteban, M., Marzo, M., Robles, S., Santanach, P., Solé Sugrañés, L., 1979, Evolución tectonoestratigráfica de los Catalánides: Acta Geologica Hispanica, 14, 242-270.

Anadón, P., Cabrera, L., Guimerà, J., Santanach, P., 1985, Paleogene strike-slip deformation and sedimentation along the Southeastern margin of the Ebro basin, in Biddle, K.T., ChristieBlick, N., (eds.),Strike-slip deformation, basin formation and sedimentation: Society of Economic Paleontologists and Mineralogists, Society for Sedimentary Geology, Special Publication, 37, 303-318.

Anadón, P., Julivert, M., Sáez, A., 1983, Aportación al conocimiento del Carbonífero de las Cadenas Costeras Catalanas: Madrid, Spain, Instituto Geológico y Minero de España, in: Compte rendu X Congrès International de Stratigraphie et de Géologie du Carbonifère (Madrid, 1983), 1, 99-106. 
Ball, S.H., 1941, The Mining of Gems and Ornamental Stones by American Indians: Washington D.C., U.S.A., Smithsonian Institution, Bureau of American Ethnology Bulletin, 128(13), 77 p.

Blasco, A., Edo, M., Villalba, M.J., 1991, Les perles en Callaïs du Sud de la France proviennentelles des Mines de Can Tintorer?, in Ambert, $\mathrm{P}$ (ed.), Le Chalcolithique en Languedoc, ses relations extra-regionales: Montpellier, France, Conseil Général de l'Hérault, Federation Archeologique de L'Herault, 279-289.

Blasco, A.,Villalba, M.J., Edo, M., 1992, Cronologia del complex miner de Can Tintorer. Aportacions a la periodització del Neolític mitjà Català, in 9è Col loqui Internacional d'Arqueologia de Puigcerdà : Puigcerdá, Catalonia, Institut d'Estudis Ceretans, 215-219.

Blasco, M., Borrell, M., Bosch, J., 2000, Las minas prehistóricas de Gavà (Barcelona): un ejemplo de estudio, conservación y presentación pública de un yacimiento arqueológico: Trabajos de Prehistoria, 57(2), 77-87

Borrell, F., 2009, La indústria lítica neolítica tallada en sílex de les mines 83, 84, 85 i 90 (Gavà, Baix Llobregat): morfologia i tecnología, in Bosch,J., Borrell,F. (eds.): Intervencions arqueològiques a les Mines de Gavà (sector serra de les Ferreres), Anys 1998-2009, De la variscita al ferro: neolític i antiguitat: Rubricatum, 4, 109-124.

Borrell, F., Bosch, J., 2012, Las mines de variscita de Gavà (Barcelona) y las redes de circulación en el Neolítico: Rubricatum, 5, 315-322.

Borrell, F., Estrada, A., 2009, Elements ornamentals neolítics de variscita trobats a les mines 83 i 85 de Gavà, in Bosch, J., Borrell, F. (eds.), Intervencions arqueològiques a les Mines de Gavà (sector serra de les Ferreres,
Anys 1998-2009, De la variscita al ferro: neolític i antiguitat: Rubricatum, 4, 165-174.

Borrell, F., Orri, E., 2009, Excavacions arqueològiques a la serra de les Ferreres, Mines Prehistòriques de Gavà, in L'Arqueologia a Gavà. Homenatge a Alícia Estrada: Gavà, Catalonia, Ajuntament de Gavà, Amics del Museu de Gavà, Collecció La Nostra Gent, 5, 67-86.

Borrell, F., Estrada, A., Bosch, J., Orri, E., 2005, Excavaciones recientes en las minas neolíticas de Gavà -sector sierra de las Ferreres-(Baix Llobregat, Barcelona): nuevos datos para el conocimiento de los rituales funerarios, in Arias, P., Ontañón, R., García-Moncó, C. (eds.), III Congreso del Neolítico en la Península Ibérica: Santander, Spain, Universidad de Cantabria, 635-642.

Borrell, F., Bosch, J., Vicente, O., 2009, Datacions per radiocarboni a les mines neolítiques de $\mathrm{La}$ Serra de Les Ferreres de Gavà: Rubricatum, $4,241-246$.

Borrell, F., Bosch, J., Majó, T., 2015, Life and death in the Neolithic variscite mines at Gavà (Barcelona, Spain): Antiquity, 89(343), 72-90.

Borruel-Abadía, V., Barrenechea, J.F., GalánAbellán, A.B., Alonso-Azcárate, J., De la Horra, R., Luque, F.J., López-Gómez, J., 2016, Quantifying aluminium phosphatesulphate minerals as markers of acidic conditions during the Permian-Triassic transition in the Iberian Ranges, E Spain: Chemical Geology, 429, 10-20.

Bosch, J., 2010, Representaciones antropomorfas muebles del Neolítico en Cataluña: primeros ídolos oculados, in Cacho, G., Maicas, R., Galán, E., Martos,J.A. (eds.), Ojos que nunca se cierran, ídolos en las primeras sociedades campesinas: Madrid, Spain, Museo Arqueológico Nacional, 13-38. 
Bosch, J., Estrada, A., 1994, La Venus de Gavà (Barcelona). Una aportación fundamental para el estudio de la religión neolítica del suroeste europeo: Trabajos de Prehistoria, 51(2), 149-158.

Bosch,J., Gómez, A., 2009, Estudide les ceràmiques neolítiques procedents de les mines 83, 84, 85 i 90 de Gavà, in Bosch, J., Borrell, F. (eds.): Intervencions arqueològiques a les Mines de Gavà (sector serra de les Ferreres), Anys 1998-2009, De la variscita al ferro: neolític i antiguitat: Rubricatum, 4, 63-83.

Bosch, J., Cuesta, F., Arenas, J., 1987, Memòria de les excavacions arqueològiques al jaciment de can Tintorer-carrer Roger de Flor (GavàBaix Llobregat). 1985-1986: Barcelona, Catalonia, Generalitat de Catalunya, Direcció General del Patrimoni Cultural, 363, 6 p.

Bosch, J., Estrada, A., Noain, M.J., 1996, Minería neolítica en Gavá (Baix Llobregat, Barcelona): Trabajos de Prehistoria 53(1), 59-71.

Bosch, J., Gibaja, J.F., Gratuze, B., 2009, Estudi d'una peça neolítica d'obsidiana procedent de la mina 83 de Gavà: tipologia, funcionalitat i petrologia, in Bosch, J., Borrell, F. (eds.): Intervencions arqueològiques a les Mines de Gavà (sector serra de les Ferreres), Anys 1998-2009, De la variscita al ferro: neolític i antiguitat: Rubricatum, 4, 133-137.

Calvet, F., Ramón, X., 1987, Estratigrafía, sedimentología y diagénesis del Muschelkalk inferior de los Catalánides: Cuadernos de Geología Ibérica, 11, 141-169.

Calvet, F., March, M., Pedrosa, A., 1987, Estratigrafía, sedimentología y diagénesis del Muschelkalk superior de los Catalánides: Guadernos de Geología Ibérica, 11, 171-198.

Camprubí, A., Costa, F., Melgarejo, J.C., 1994, Mineralizaciones de fosfatos férricoalumínicos de Gavà (Catalunya): tipología: Boletín Geológico y Minero, 105(5), 444-453.
Camprubí, A., Melgarejo, J.C., Proenza, J.A., Costa, F., Bosch, J., Estrada, A., Borrell, F., Yushkin, N.P., Andreichev, V.L., 2003, Mining and geological knowledge during the Neolithic: a geological study on the variscite mines at Gavà, Catalonia: Episodes, Journal of International Geoscience, 26, 295-301.

Casas, A., Majó, T., 2009, Estudi arqueoantropològic de les restes humanes neolítiques de les mines 84 i 90 de Gavà (Baix Llobregat), in Bosch, J., Borrell, F. (eds.), Intervencions arqueològiques a les Mines de Gavà (sector serra de les Ferreres), Anys 1998-2009, De la variscita al ferro: neolític i antiguitat: Rubricatum, 4, 209-223.

Casassas, L., Riba, O., 1992, Morfologia de la Rambla barcelonina: Treballs de la Societat Catalana de Geografia, 7(33-34), 9-27.

Costa, F., Camprubí, A., Salvany, M.C., Sáez, G., Arcas, A., Melgarejo, J.C., 1993, The phosphate mineralizations from Gavà, Catalonia, Spain, in Gervilla, F., Fenoll, P., Torres, J. (eds.), Current research in geology applied to ore deposits, Proceedings of the 2nd SGA Biennial Meeting: Granada, Spain, Universidad de Granada, 715-718.

Costa, F., Camprubí, A., Melgarejo, J.C., 1994, Aproximación geológica a las minas neolíticas de fosfatos férrico-alumínicos de Gavà (Cataluña): Boletín Geológico y Minero, 105(5), 436-443.

Daura,J., Sanz, M., García, N., Allué, E., Vaquero, M., Fierro, E., Carrión, J.S., López-García, J.M., Blain, H.A., Sánchez-Marco, A., Valls, C., Albert, R.M., Fornós, J.J., Julià, R., Fullola,J.M., Zilhão, J., 2013, Terraces of the Riera dels Canyars (Gavà, Barcelona): the landscape of Heinrich Stadial 4 north of the "Ebro frontier" and implications for modern human dispersal into Iberia: Quaternary Science Reviews, 60, 26-48. 
Díaz-Acha, Y., Campeny, M., Melgarejo, J.C., Bosch, J., Lehbib, S., Torró, L., Proenza, J.A., Castillo-Oliver, M., Camprubí, A., Villanova-de-Benavent, C., Andreazini, A., Pastor, M., Pujol-Solà, N., Amores, S., Xu, J., Farré, J., 2019, Geological context and origin of the mineralization of the historic and prehistoric iron mines in the Gavà area, Catalonia: Boletín de la Sociedad Geológica Mexicana, 71(2), 321-342.

Dill, H.G., Busch, K., Blum, N., 1991, Chemistry and origin of vein-like phosphate mineralization, Nuba Mts. (Sudan): Ore Geology Reviews, 6(1), 9-24.

Domínguez-Bella, S., 2004, Variscite, a prestige mineral in the Neolithic-Aeneolithic Europe. Raw material sources and possible distribution routes: Slovak Geological Magazine, 10(1-2), 147-152.

Edo, M., Blasco, A., Villalba, M.J., 1990, Approche de la carte de distribution de la variscite des Mines de Can Tintorer, Gavà (Catalogne): Cahiers du Quaternaire, 17, 287-298.

Edo, M., Villalba, M.J., Blasco, A., 1995, La calaíta en al Península Ibérica: Trabalhos de Antropología e Etnología, 35(2), 127-167.

Enrique, P., 1990, The Hercynian intrusive rocks of the Catalan Coastal Ranges (NE Spain): Acta Geologica Hispanica, 25(1-2), 39-64.

Fernández-Turiel, J.L., Jimeno, D., Plana, F., Blasco, A., Edo, M., Villalba, M.J., 1990, Estudio de las mineralizaciones fosfáticas del complejo minero de Can Tintorer (Gavà, Barcelona) y comparación con las cuentas procedentes de ajuares arqueológicos: Boletín de la Sociedad Española de Mineralogía, 13(1), 86-87.

Fernández-Turiel, J.L, Blanco Majado, J., López Alonso, M., Edo, M., 1995, Estudio analítico de determinación mineralógica y de composición química de las cuentas de collar de calíta y otras materias primas del yacimiento de Las Peñas (Quiruelas de Vidriales, Zamora): Rubricatum, 1, 227-237. Galán-Abellán, B., Alonso-Azcárate, J., Newton, R.J., Bottrell, S.H., Barrenechea, J.F., Benito, M.I., De La Horra, R., López-Gómez, J., Luque, J., 2013, Sources of Sr and S in aluminum-phosphate-sulfate minerals in early-middle Triassic sandstones (Iberian Ranges, Spain) and paleoenvironmental implications for the west Tethys: Journal of Sedimentary Research, 83(5), 406-426.

García-López, S., Julivert, M., Soldevila, J. Truyols-Massoni, M., Zamarreño, I., 1990, Bioestratigrafía y facies de la sucesión carbonatada del Silúrico Superior y Devónico Inferior de Santa Creu d'Olorda (Cadenas Costero Catalanas, NE de España): Acta Geologica Hispanica, 25(1-2), 141-168.

García-López, S., Rodríguez-Cañero, R., SanzLópez, J., Sarmiento, G., Valenzuela-Ríos,J.I., 1996, Conodontos y episodios carbonatados en el Silúrico de la Cadena Hercínica meridional y del Dominio Sahariano: Revista Española de Paleontología, extraordinary issue, 33-57.

Gaspar-Escribano, J. M., Garcia-Castellanos, D., Roca, E., Cloetingh, S., 2004, Cenozoic vertical motions of the Catalan Coastal Ranges (NE Spain): The role of tectonics, isostasy, and surface transport: Tectonics, 23, TC1004.

Gimeno, D., Fernández-Turiel, J.L., Villalba, M.J., Edo, M., Blasco, A., 1995, Complejo minero de Can Tintorer, Gavà: Geología y técnicas de explotación en el IV milenio: Rubricatum, 1, 259-263.

Guimerà, J., 1984, Palaeogene evolution of deformation in the north-eastern Iberian peninsula: Geological Magazine, 121(5), 413-420. 
Herbaut, F., Querré, G., 2004, La parure néolithique en variscite dans le sud de l'Armorique: Bulletin de la Société Préhistorique Française, 101(3), 497-520.

Julivert, M., Duran, H., 1990, Paleozoic stratigraphy of the Central and Northern part of the Catalalonian Coastal Ranges (NE Spain): Acta Geologica Hispanica, 25(1-2), 3-12.

Julivert, M., Duran, H., Rickards, R.B., Chapman, A.J., 1985, Siluro-Devonian graptolite stratigraphy of the Catalonian Coastal Ranges: Acta Geologica Hispanica, 20(3-4), 199-207.

Manutchehr-Danai, M., 2000, Dictionary of gems and gemology: Berlin, Germany, SpringerVerlag, $564 \mathrm{p}$.

Mata-Perelló, J.M., Plana, F., Travería, A., 1983, Estudio mineralógico del yacimiento de fosfatos de Gavà: Boletín Sociedad Española de Mineralogía, 7, 257-258.

Meireles, C., Ferreira, N., Reis, M.L, 1987, Variscite Occurrences in Silurian Formations from Northern Portugal: Comunicações dos Serviços Geológicos de Portugal, 73, 21-27.

Melgarejo, J.C., Fontan, F., Alfonso, P., Camprubí, A., Costa, F., Salvany, M., Sáez, G., Arcas, A., 1997, Asociaciones minerales de rocas fosfatadas sedimentarias y sus derivados meteóricos y metamórficos, in Melgarejo, J.C. (ed.), Atlas de asociaciones minerales en lámina delgada: Barcelona, Catalonia, Edicions de la Universitat de Barcelona, 323-332.

Melgarejo, J.C., Cirera, M.C., Proenza, J., 2009, Estudi geològic i mineralògic de mines de l'època neolítica a la Serra de Les Ferreres (Mines de Gavà): Rubricatum, 4, 47-61.

Morad, S., Al-Aasm, I.S., Longstaffe, F., Marfil, R., De Ros, L.F., Johansen, H., Marzo, M., 1995, Diagenesis of a mixed siliciclastic/evaporitic sequence of the Middle Muschelkalk (Middle Triassic), the Catalan Coastal Range, NE Spain: Sedimentology, 42(5), 749-768.
Noain, M.J., 1996, Las cuentas de collar en variscita de las minas prehistóricas de Gavà (Can Tintorer): bases para un estudio experimental: Cuadernos de Prehistoria y Arqueología, 23, 37-86 .

Odriozola, C.P., Linares-Catela, J.A., Hurtado Pérez, V., 2010, Variscite source and source analysis: testing assumptions at Pico Centeno (Encinasola, Spain): Journal of Archaeological Science, 37(12), 3146-3157.

Odriozola, C.P., Linares-Catela, J.A., HurtadoPérez, V.M., 2013, Provenancing variscite beads: Pico Centeno (Encinasola, Spain) outcrop case study: Open Journal of Archaeometry, 1:e17, 80-84.

Pe-Piper, G., Dolansky, L.M., 2005, Early diagenetic origin of $\mathrm{Al}$ phosphate-sulphate minerals (woodhouseite and crandallite series) in terrestrial sandstones, Nova Scotia, Canada: American Mineralogist, 90(8-9), 1434-1441.

Riba, O., Colombo, F., 2009, Barcelona: la Ciutat Vella i el Poble Nou. Assaig de Geologia urbana: Barcelona, Catalonia, Institut d'Estudis Catalans, Reial Acadèmia de les Ciències i les Arts de Barcelona, 278 p.

Salas, R., 1987, El Malm i el Cretaciinferior entre el Massís de Garraf i la Serra d'Espadà. Anàlisi de conca: Barcelona, Catalonia, Universitat de Barcelona, Department de Geoquíica, Petrologia I Prospecció Geològica, PhD Dissertation, 345 p.

Solé Benet, A., Julià Brugués, R., Ballbé Llonch, E., 1988, Micromorfología y Mineralogía de un paleosuelo pleistoceno del Pla de Barcelona: Acta Geologica Hispanica, 23(3), 197-207.

Villalba, M.J., 2002, Le gîte de variscite de Can Tintorer: Production, transformation, et circulation du minéral vert, in Guilaine, $\mathrm{J}$. (ed.), Matériaux, productions, circulations du Néolithique à l'âge du bronze: Paris, France, Éditions Errance, 115-129. 
Villalba, M.J., Edo, M., 1991, Aspectes sobre la mineria subterrània i la tecnologia aplicada als sistemes d'exploració: Puigcerdà, Catalonia, Institut d'Estudis Ceretans, 9è Col loqui Internacional d'Arqueologia de Puigcerdà, Estat de la investigació sobre el Neolític a Catalunya, 195-199.

Villalba, M.J., Bañolas, L., Arenas, J., Alonso, M., 1986, Les mines neolítiques de Can Tintorer (Gavà): excavacions 1978-1980: Barcelona, Catalonia, Departament de Cultura de la Generalitat de Catalunya, Excavacions Arqueològiques a Catalunya, 6, 203 p.

Villalba, M.J., Blasco, A., Edo, M., Arenas, J., Bañolas, L., 1989, Minería neolítica: Can
Tintorer, una aportación fundamental: Revista de Arqueología, 96, 13-24.

Villalba, M.J., Bañolas, L., Arenas, J., 1990, Can Tintorer (Gavà, Catalunya): une exploitation néolithique de phosphates et silicates: Cahiers du Quaternaire, 17, 275-285.

Villalobos, R., Odriozola, C.P., 2016, Organizing the production of variscite personal ornaments in later Prehistoric Iberia: the mines of aliste and the production sites of Quiruelas de Vidriales (Zamora, Spain): European Journal of Archaeology, 19(4), 631-651.

Virgili, C., 1958, El Triásico de los Catalánides: Boletín del Instituto Geológico y Minero de España, 69, 858 p. 